\title{
Splićani - Croati a cavallo u mletačkim prekojadranskim kopnenim postrojbama u 18. stoljeću
}

Središnje istraživačko zanimanje ovoga rada usmjereno je na proučavanje udjela Splićana u profesionalnoj mletačkoj konjaničkoj postrojbi (Croati a cavallo, Cavalleria Croati) tijekom 18. stoljeća. Rad se zasniva na istraživanju gradiva iz Archivio di Stato di Venezia (fond: Inquisitori sopra l'amministrazione dei pubblici ruoli). Na osnovi navedenoga gradiva, kao i postojećih spoznaja iz historiografije, analizira se vremenski okvir djelovanja Splićana u rečenoj postrojbi, način njihova bilježenja, trajanje vojne službe, udio pripadnika iz istih obitelji, osobne (tjelesne) značajke vojnika, kao i mjesto njihova popisivanja te zapovjedni kadar jedinica u kojima su bili prisutni. Zaključak rada jest da su Splićani činili vrlo zapažen dio hrvatskoga konjaništva pod stijegom Serenissime te da ovdje provedena raščlamba teži pridonijeti boljemu poznavanju vojne povijesti Dalmacije (u konkretnome slučaju grada Splita) i Mletačke Republike u posljednjemu stoljeću njihova opstojanja u zajedničkoj državi.

Ključne riječi: Split, Dalmacija, Mletačka Republika, Cavalleria Croati, vojna povijest, povijest 18. stoljeća.

\section{Uvod i cilj rada}

Prekojadranske (prekomorske) kopnene postrojbe mletačke vojske - pješaštvo i konjaništvo - novačene ponajprije duž stečevina Republike svetoga Marka od sjevera Istre do albanskoga juga u ranome su novom vijeku imale prevažnu ulogu u očuvanju njezinih posjeda kako na području Stato da Mar, tako i duž kopnenih dijelova Veneta (terraferma). Djelatne još od prvih mletačko-osmanskih ratova koncem 15 . i u 16. stoljeću te su postrojbe svoju najveću brojnost i najzapaženiju vojnu učinkovitost imale tijekom 17. stoljeća (Kandijski rat: 1645. - 1669.; Morejski rat: 1684. - 1699.) i početkom 18. stoljeća (Drugi morejski ili Mali rat: 1714. - 1718.). Nakon 1718. godine i sklapanja Požarevačkoga mira dolazi do postupnoga preustroja mletačke vojske te je njezina brojnost smanjena, ali su i u mirnodopsko vrijeme -već u velikoj mjeri etablirane kao uspješne i državi neophodne postrojbe - nastavile svoje djelovanje sve do utrnuća Serenissime. ${ }^{1}$ Kada je riječ o užoj podjeli mletačkih prekomorskih kopnenih

\footnotetext{
* Lovorka Čoralić, Hrvatski institut za povijest, Opatička 10, 10000 Zagreb, Republika Hrvatska, E-mail adresa: lovorka@isp.hr

1 O mletačkim vojnim snagama u ranome novom vijeku, posebice s obzirom na novačenja na području mletačkoga Stato da Mar, vidi bibliografske jedinice navedene u radovima Lovorke Čoralić,
} 
snaga, važnošću se posebice izdvajaju pješaštvo (onovremeno mornaričko pješaštvo) pod imenom Fanti oltramarini i hrvatsko konjaništvo - Croati a cavallo (Cavalleria Croati). ${ }^{2}$

Središnja tema ovoga rada, koji je nastavak višegodišnjih istraživanja gradiva iz Archivio di Stato di Venezia i Državnoga arhiva u Zadru, usmjerena je na udio Splićana u mletačkim prekomorskim konjaničkim postrojbama tijekom 18. stoljeća. Glavni izvor koji je uporabljen u ovome radu spisi su mletačke državne magistrature za novačenje kopnenih postrojbi poznate pod nazivom Inquisitori sopra l'amministrazione dei pubblici ruoli, a koji su pohranjeni u Archivio di Stato di Venezia (dalje: RI-ASVe-0715-Inquisitori ... pubblici ruoli). Riječ je o popisima pripadnika pojedinih pukovnija i njima pripadajućih satnija, koji su većim dijelom sačuvani upravo za 18 . stoljeće.

Tragom navedenih izvora i postojećih historiografskih spoznaja u ovome ćemo tekstu podrobnije ukazati na način bilježenja Splićana u elitnoj prekomorskoj konjaničkoj postrojbi Cavalleria Croati, ${ }^{3}$ vremenski okvir spominjanja, utvrditi njihove činove, trajanje vojne službe, tjelesne (osobne) karakteristike vojnika te spomenuti njihove vojne zapovjednike i navesti mjesta popisivanja. Naposljetku, na kraju rada donijet ćemo u formi tabličnoga priloga poimenični pregled svih do sada istraženih splitskih vojnika u konjaničkim prekomorskim postrojbama Mletačke Republike, pri čemu je kao osnova poslužila baza podataka iz spomenutoga fonda Inquisitori sopra l'amministrazione dei pubblici ruoli. ${ }^{4}$

\footnotetext{
“Zadarski otočani u mletačkim prekomorskim kopnenim postrojbama (18. stoljeće)”, Zbornik Odsjeka za povijesne znanosti Zavoda za povijesne i društvene znanosti HAZU 33 (2015): 174 i “Albanski vojnici u mletačkim prekojadranskim kopnenim postrojbama (18. stoljeće)”, Povijesni prilozi 37 (2018), br. 54: 185-186.

2 Podrobnije o ustroju i strukturi postrojbi Fanti oltramarini i Croati a cavallo vidi u: Francesco Paolo Favaloro, L'Esercito Veneziano del '700. Ricerche e schizzi (Venezia: Filippi Editore, 1995), 57-58, 100-103; Alberto Prelli, Sotto le bandiere di San Marco: Le armate della Serenissima nel '600 (Bassano del Grappa: Itinera progetti, 2012.), 71-106; Lovorka Čoralić, Maja Katušić, "Kotorski plemići Frano Buća, Gabrijel Vraćen i Nikola Paskvali - časnici mletačkih prekojadranskih vojnih postrojbi (prva polovica XVIII. st.)", Povijesni prilozi 31 (2012), br. 42: 250-252. Usporedi dodatno i ondje navedene bibliografske jedinice o navedenoj problematici.

3 Radi opsežnosti gradiva ovdje će ponajprije biti obrađen udio Splićana u konjaničkim postrojbama, a njihov udio u pješaštvu bit će predmet zasebnoga rada. Ovdje je potrebno napomenuti da uzorak obrađenih postrojbi hrvatskoga konjaništva iznosi više od 50 \%. Također, kako bismo izbjegli opterećivanje teksta suvišnim bilješkama, na kraju rada donosi se cjelovit pregled svih do sada istraženih splitskih konjanika sa svim potrebnim podacima i arhivskim signaturama.

4 O hrvatskim regionalnim skupinama u mletačkim prekojadranskim kopnenim postrojbama vidi, primjerice: Lovorka Čoralić, "Riječani u mletačkim prekojadranskim postrojbama (18. stoljeće)”, Rijeka 18 (2013), br. 2: 11-25; Lovorka Čoralić, "Vojnici iz Hercegovine u mletačkim kopnenim postrojbama (18. stoljeće)", Hum: Časopis Filozofskog fakulteta Sveučilišta u Mostaru 10 (2013): 162-182; Lovorka Čoralić, "Vojnici u mletačkim prekomorskim kopnenim postrojbama zavičajem iz Senja, Karlobaga te s područja Like i Krbave (18. stoljeće)”, Senjski zbornik 40 (2013): 523-546; Lovorka Čoralić, “Dubrovčani - vojnici u mletačkim pješačkim postrojbama (Fanti oltramarini) u 18. stoljeću”, Anali Zavoda za povijesne znanosti HAZU u Dubrovniku 53 (2015), br. 2: 293-309; Lovorka Čoralić, "Vojnici iz Bosne u mletačkim prekomorskim kopnenim postrojbama u 18. stoljeću”, Prilozi - Institut za istoriju u Sarajevu 44 (2015): 35-55; Čoralić, “Zadarski otočani”: 173-198; Lovorka Čoralić, Maja Katušić, “Šibenčani u
} 


\section{Raščlamba arhivskih spisa}

Broj do sada istraženih konjanika iz Splita u mletačkim prekojadranskim postrojbama iznosi 56, dočim je broj pješaka iznosio 109 . Takav je omjer $(33,94 \%$ naspram 66,06 \%; vidi: Grafikon 1) očekivan, posebice kada se radi o vojnicima iz uzmornih gradova i s otoka. ${ }^{5}$ Usporedbe radi, kada je riječ o vojnicima iz Drniša, Imotskoga i Sinja, dakle iz dalmatinskoga zaleđa, evidentna je prevaga konjanika. ${ }^{6}$ Razlog tome možemo tražiti u činjenici da je stanovništvo zaleđa, gotovo netom oslobođenoga od osmanske vlasti, bilo usmjereno na poljodjelske aktivnosti kao i na tranzitnu trgovinu. Za to su kao sredstvo svakodnevnoga rada konji bili neophodni te je stoga rečena populacija bila vičnija vještinama koje su bile prijeko potrebne profesionalnim vojnicima u konjaničkim postrojbama. Nasuprot tome, gradsko stanovništvo ponajprije je bilo usmjereno na obrt, trgovinu i pomorstvo, odnosno na zanimanja koja najčešće nisu bila u bliskoj svezi sa poljodjelstvom i stočarstvom. Isto tako, potrebno je napomenuti da su konjaničke postrojbe u odnosu na pješaštvo bile financijski znatno skuplje i manje mobilne te je tijekom preustroja mletačke vojske - nakon prestanka mletačko-osmanskih ratova (Požarevački mir, 1718. godine) - njihova brojnost smanjena. ${ }^{7}$ Uza sve navedeno proizlazi činjenica da prevaga pješaka, barem kada je riječ o gradskome stanovništvu, nije neočekivana iako su i tu, ovisno o pojedinome vremenskom razdoblju, moguća određena odstupanja i neujednačenosti.

mletačkim prekojadranskim kopnenim postrojbama (18. stoljeće)", Radovi Zavoda za povijesne znanosti HAZU u Zadru 58 (2016): 147-190; Lovorka Čoralić, Maja Katušić, "Novigrađani - vojnici u mletačkim prekomorskim kopnenim postrojbama u 18. stoljeću", u: Novigrad nekad i sad, ur. Slobodan Kaštela (Zadar: Sveučilište u Zadru; HAZU; Matica hrvatska; Općina Novigrad, 2016), 352-359; Lovorka Čoralić, Maja Katušić, "Fanti oltramarini i Croati a cavallo - vojnici s otoka Ugljana u mletačkim prekomorskim kopnenim postrojbama u 18. stoljeću”, u: Kali, ur. Josip Faričić (Zadar: Sveučilište u Zadru; HAZU; Općina Kali, 2017), 163-178; Lovorka Čoralić, Maja Katušić, "Biograđani i Vranjani vojnici u mletačkim prekomorskim kopnenim postrojbama (18. stoljeće)" u: Braća Vranjanin i vransko područje tijekom povijesti. Zbornik radova sa znanstvenoga skupa "Braća Vranjanin i vransko područje tijekom povijesti” održanog u Biogradu 25. travnja 2014., ur. Božo Došen (Zadar: Ogranak Matice hrvatske u Zadru; Općina Pakoštane, 2017), 455-474.

5 Primjerice, iz Šibenika bilježimo 53,81 \% pješaka i 46,19 \% konjanika, a iz Trogira 66,27 \% pješaka i 33,73 \% konjanika. Usporedi: Čoralić, Katušić, "Šibenčani u mletačkim prekojadranskim kopnenim postrojbama”, 151. Rad o udjelu Trogirana u mletačkim prekomorskim postrojbama je u pripremi, a potrebni izračuni koji su ovdje navedeni već su načinjeni.

6 Omjer prema navedenim gradovima iznosi: Drniš 80,81 \% konjanika i 19,19 \% pješaka; Imotski 61,90 \% konjanika i 38,10 \% pješaka; Sinj i Cetinska krajina 60,53 \% konjanika i 39,47 \% pješaka. Izračuni su dobiveni prethodno načinjenom znanstvenom obradom istoga izvora temeljem kojega je načinjen i ovaj rad o splitskim prekomorskim vojnicima. O udjelu prekomorskih vojnika iz navedenih gradova pripremaju se zasebne znanstvene studije.

Tijekom 18. stoljeća istovremeno je djelovalo oko deset prekomorskih pješačkih pukovnija, a unutar njih sedam do deset satnija s oko pedeset do šezdeset ljudi. Konjaničke su pukovnije bile manje brojne, najčešće ih je bilo pet do šest, od kojih su dvije do tri bile Cavalleria Croati, a ostale draguni. Unutar konjaničkih pukovnija djelovalo je obično šest do sedam satnija. Usporedi: Favaloro, L'Esercito Veneziano, 137-142. 


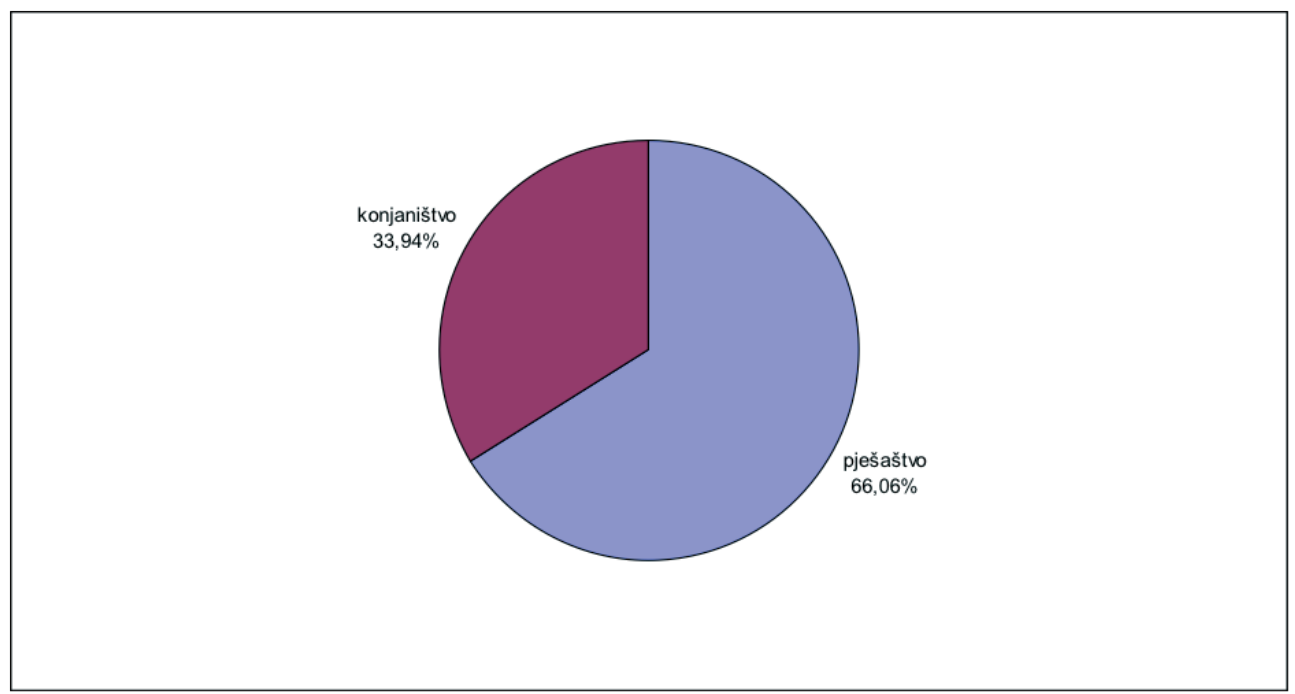

Grafikon 1. Omjer zastupljenosti Splićana u pješačkim i konjaničkim postrojbama

Splićani su u popisima pripadnika konjaničkih snaga bilježeni na jednoobrazan način. Popisivači su, uz manja odstupanja, upisivali ime, očevo ime i prezime vojnika odnosno časnika ili dočasnika, mjesto njihova podrijetla (Spalato, Spalatro, de Spalato), naziv pukovnije i satnije kojoj je dotični vojnik pripadao kao i mjesto njezina trenutačnog djelovanja i popisivanja. Uz navedeno ponekad su, ali ne redovito, zabilježeni i osobni podaci o vojnicima (dob, statura, boja kose, boja konja). Upravo će ovdje navedeni podaci u nastavku rada biti predmetom pomnije obrade. Imena i prezimena ovdje analiziranih Splićana najčešće su upisana u talijanskim (venetiziranim) oblicima, ali u nekim je primjerima zabilježen i njihov hrvatski oblik.

Vremenski okvir djelovanja splitskih konjanika zahvaća cijelo 18. stoljeće iako ne is jednakim intenzitetom (vidi: Grafikon 2). Naime, u početnim desetljećima rečenoga stoljeća (do oko 1740. godine) opaža se - razmjerno ukupnome brojčanom uzorku zapaženiji broj Splićana. Njihovo je djelovanje zasigurno (ali o tome nemamo potvrde u ovdje analiziranome arhivskom gradivu) zahvaćalo i drugu polovicu, odnosno kraj 17. stoljeća (osobito Morejski rat), a nastavljalo se i tijekom Drugoga morejskog rata kada uslijed novačenja svekolikih kopnenih snaga za obranu mletačkih stečevina duž Stato da Mar postiže najveću brojnost. U sljedećim desetljećima, nakon 1718 . godine i tijekom dvadesetih godina, kada nastupa mirnodopsko vrijeme i samim time dolazi do preustroja (smanjenja) aktivnih pješačkih i (osobito) konjaničkih pukovnija i satnija, broj Splićana u postrojbama Croati a cavallo smanjuje se iako sve do šezdesetih godina 18. stoljeća zadržava relativno visoku razinu bilježenja. U posljednjim desetljećima opstanka Serenissime broj Splićana u profesionalnim konjaničkim postrojbama dodatno opada, ali je - unatoč tome - njihova prisutnost u elitnim jedinicama i dalje primjetna. Susljedno prethodno navedenoj raščlambi udjela Splićana u konjaničkim snagama Republike svetoga Marka moguće je utvrditi i početne odnosno završne 
godine spominjanja pojedinih vojnika. Kada je riječ o prvome spomenu Splićana u konjaništvu, kao početnu bilježimo 1703. godinu kada je na području mletačkih stečevina u Grčkoj zabilježen Augustin Karlov Stomić, pripadnik pukovnije Antuna Medina. Završna ubilježba nekoga od splitskih konjanika u izvorima datira u 1796. godinu, točnije u vrijeme kada pred neposredan silazak s pozornice europske sile Mletačka Republika po posljednji puta mobilizira znatnije vojne snage. Udio splitskih konjanika ovdje je primjetan, ali ujedno i mnogo manje izrazit u odnosu na sam početak istoga stoljeća. U konkretnome slučaju riječ je o konjaničkoj postrojbi osobne satnije pukovnika Antuna Radnića, popisanoj u Mlecima na Silvestrovo, a splitski je akter vojnik Petar Vicko Manzoni.

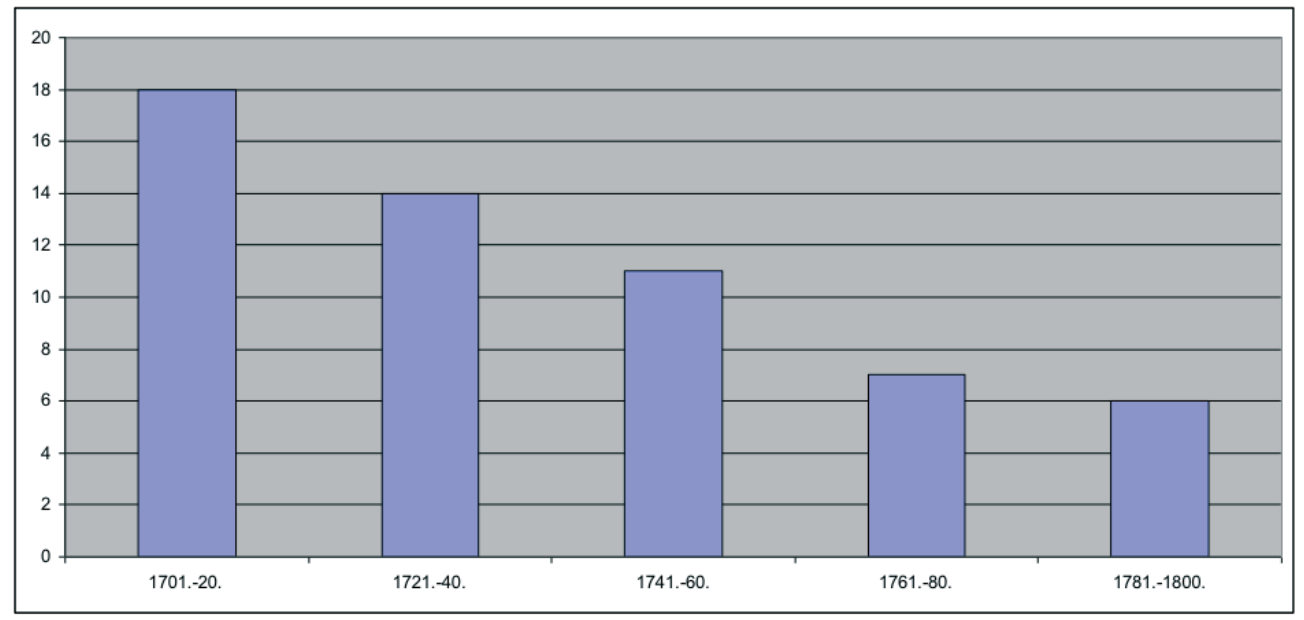

Grafikon 2. Vremenski okvir bilježenja splitskih konjanika u analiziranim vrelima

Brojni su vojnici, kako pješaci, tako i konjanici, u pojedinim jedinicama spomenuti samo jednom te je njihovu kasniju karijeru prema dosadašnjemu stupnju istraženosti gradiva gotovo nemoguće podrobnije pratiti. Ipak, za niz splitskih konjanika moguće je, zahvaljujući kontinuiranoj sačuvanosti popisa, pratiti tijek njihove vojne službe. Splitski pripadnik Cavalleria Croati s najduže zabilježenim vojnim stažem bio je Stjepan Matijin Dujmović, djelatan od 1724. do 1763. godine (39 godina), vojnik u sastavu postrojbi kojima su kao pukovnici zapovijedali Lujo Detriko te potom Franjo Buća. Značajan, ali ni približno tako dug tijek službe opažamo i u primjeru Antuna Ivanovog Panasovića, popisivanoga u razmaku od 1754. do 1773. godine u postrojbama Šimuna Benje te pukovnika i potom bojnika vojske i nadintendanta hrvatske konjice Franje Buće. Nadalje, s više od deset godina službe izdvajaju se braća Antun i Lujo Vicanović/Vianović, Filipovi sinovi, konjanici koji se u ovim vrelima bilježe od 1724. do 1741. godine (uvijek u pukovniji i osobnoj satniji Luje Detrika) kao i Antun Petrov Andreis, redovito pripadnik osobne satnije pukovnika Tripuna Gregorine od 1775. do 1790. godine. 
Zanimljivo je spomenuti i udio članova iz istih obitelji u mletačkoj konjaničkoj službi. Takvi slučajevi bili su česti i u primjeru drugih vojnika (kako pješaka, tako i konjanika) iz hrvatskih krajeva te tako ne izostaju i pri raščlambi dokumenata o splitskim konjanicima. Primjerice, iz obitelji Bolis/Bolić u isto su vrijeme (1754.) u pukovniji Luje Karla Benje bili su upisani otac Antun i njegov sin Josip. Od 1727. do 1728. godine u pukovniji Luje Detrika zabilježeni su braća Ivan i Mihovil Dračić, Ivanovi sinovi, a pod vodstvom istoga zapovjednika bilježe se već prethodno spomenuta braća Antun i Lujo Vicanović/Vianović. Naposljetku, u osobnoj satniji pukovnika Tripuna Gregorine bilježe se Vice Franin Čipčić (1775.) te njegovi sinovi Andrija (1786. - 1790.) i Ivan (1786. - 1789.).

U sklopu proučavanja djelovanja časnika, dočasnika i vojnika iz raznih hrvatskih krajeva i gradova važnu je sastavnicu imala i raščlamba pojedinaca odnosno pripadnika pojedinih obitelji koji su tijekom karijere postizali najviše časničke činove (pukovnika, generala). Primjerice, u Zadru su to bili članovi obitelji Benja, Detriko, Fanfonja, Nassi i drugi, iz Šibenika su se posebno izdvajali odvjetci obitelji Divnić i Fenzi, iz Trogira Michieli Vitturi i Radnić, iz Makarske obitelj Alačević, a iz Boke kotorske Buće, Gregorine, Paskvali, Vraćen i drugi. O nekima od njih, kada je riječ o zapovjednicima konjaničkih postrojbi, više će biti riječi kasnije, prilikom izravne obrade pukovnika koji su bili nadređeni splitskim konjanicima. Kada je riječ o Splićanima, opažamo da u sklopu arhivskoga fonda koji je u fokusu ovoga istraživanja ne bilježimo obnašatelje visokih časničkih činova. Poznato je, naime, da su odvjetci splitskih obitelji Alberi, Marjanović, Papali i drugih tijekom ranoga novog vijeka obnašali dužnosti kapetana i (ili) guvernadura pojedinih teritorijalnih jedinica na lokalnoj razini, često kao zapovjednici nekih utvrda ili postrojbi teritorijalne milicije (cernide, krajine). ${ }^{8}$ Međutim, u analiziranome gradu kojim ovdje raspolažemo Splićane ne nalazimo kao nositelje časničkih činova te ćemo se u ovome dijelu rada osvrnuti na bilježenje konjaničkih dočasnika i obnašatelja specijaliziranih službi u vojnim jedinicama. ${ }^{9}$ Kada je riječ o dočasnicima, Splićane u nekoliko primjera bilježimo u činu kaplara (caporal). To su Antun Petrov Andreis, kao običan vojnik zabilježen 1775. godine da bi od 1778. do 1790. godine djelovao u činu kaplara; Vice Čipčić (kaplar 1775.) i njegov sin Andrija, caporal od 1786. do 1790. godine; Stjepan Jurov Sladović (kaplar 1714.) i Frane Ivanov Stuari (kaplar 1785.) Naposljetku, kao obanašelji specijaliziranih službi u konjaničkim postrojbama izdvajaju se sedlar (seller) Martin Ivanov

8 Šime Peričić, “Glavari i časnici Vojne krajine u Dalmaciji”, Radovi Zavoda za povijesne znanosti HAZU u Zadru 35 (1993): 229-230; Nikola Markulin, "Mletačka vojna organizacija u Dalmaciji i Boki od Morejskog rata (1684. - 1699.) do Požarevačkog mira 1718.” (doktorska disertacija, Sveučilište u Zadru, 2015), passim.

9 Ovdje je ipak potrebno napomenuti da nije isključeno da je poneki Splićanin obnašao u pješačkim ili konjaničkim postrojbama neki od časničkih činova. Naime, pri upisu pripadnika pojedinih satnija za nositelje časničkih činova mjesto njihova podrijetla najčešće nije navedeno vjerojatno zato što se ono onodobnim akterima podrazumijevalo. Ipak, prezimena nositelja visokih činova koja smo spomenuli nisu ostavljala sumnju o njihovoj užoj zavičajnoj pripadnosti. Najčešće su to bili odvjetci uglednih plemićkih obitelji koje su pokoljenjima davale visoki vojni kadar mletačkoj vojsci, a u slučaju Splićana takve primjere unutar ovoga arhivskoga fonda (prema postojećim spoznajama) ne bilježimo. 
Vukas kao i glasnik (forier) Petar Sinović, a obojica su zabilježeni u često spominjanoj pukovniji Luje Detrika 1741. godine.

Važnu sastavnicu ovoga istraživanja čini i raščlamba Splićana prema njihovim dobnim i tjelesnim značajkama. Podaci o tome nisu redovito upisivani, ali je uzorak dovoljno velik da je moguće iskazati određena zapažanja. Kada je riječ o dobi, splitski konjanici u mletačkoj vojnoj službi imali su u prosjeku 34 godine. Nasuprot tome i usporedbe radi, prosječna je dob pješaka (Fanti oltramarini) iz Splita iznosila 26 godina. Takvi su podaci očekivani i objašnjeni prethodno, a jednako su tako prisutni i prilikom usporedne raščlambe dobi pješaka i konjanika iz drugih hrvatskih krajeva i gradova. ${ }^{10}$ Naime, konjaničke su jedinice bile elitnije, iziskivale su vojnike koji su u profesionalnoj službi (moguće i kao pješaci) već imali određeni broj godina službe, njihovo je umijeće ratovanja i djelovanja u sklopu zahtjevnih pravila bilo dokazano te su - susljedno tome - u postrojbe Croati a cavallo pristupali kao osobe zrelije životne dobi. U primjeru splitskih konjanika najmlađi su vojnici bili (prema prvotnome bilježenju u izvoru) Antun Filipov Vicanović/Vianović, u trenutku popisa u pukovniji Luje Detrika (Verona, 1724.) star 20 godina, i neznatno stariji (22 godine) Ivan Stjepanov Jurjević, spomenut u Veroni 1754. godine u sastavu osobne satnije pukovnika Luje Karla Benje. Kada je riječ o dobno najstarijim konjanicima, na prvome je mjestu Ivan Panasović (pukovnija Nikole Divnića, Zadar, 1729.) star 60 godina, a od starijih pripadnika Cavalleria Croati iz Splita izdvaja se još i Gabre Musanović/Musinović, pripadnik pukovnije spomenutoga Divnića (Mleci i Brescia, 1732. - 1733.) kada je bio u dobi od 50 godina.

Iako neredovito, popisivači su donosili i podatke o tjelesnome izgledu konjaničkih vojnika, ali i konja koje su oni zaduživali. Splićane su, kao i pretežit broj drugih popisanih vojnika, službenici najčešće bilježili kao osobe prosječnoga, srednjega rasta (ordinario). Nasuprot tome, vojnike opisane pridjevom visok (alto) u izvoru bilježimo samo u jednome slučaju, ${ }^{11}$ a one koji su niski (basso, piccolo) ne nalazimo u postojećim popisima. Slična, u jednome smjeru i prevladavajuća, percepcija tjelesnih značajki vojnika prisutna je i u opisu boje njihove kose. Pretežit broj splitskih konjanika bio je, prema procjeni popisivača, smeđokos (castagno), a samo u pojedinačnim primjerima bilježimo crnokose (nero) i sjedokose (grisso) vojnike. ${ }^{12}$ Opažamo, nadalje, da su po-

10 U primjeru vojnika iz Šibenika prosječna je dob pješaka iznosila 25, a konjanika 28 godina. Slično opažamo i za Trogirane: pješaci su prosječno bili stari 24, a konjanici 27 godina. Ovdje opažamo da je dobna razlika između pješaka i konjanika iz Splita ipak ponešto veća. Usporedi: Čoralić, Katušić, "Šibenčani u mletačkim prekojadranskim kopnenim postrojbama”, 156. Rad o Trogiranima u mletačkim prekojadranskim kopnenim postrojbama u pripremi je, a ovdje izneseni podaci već su prethodno znanstveno obrađeni.

11 Riječ je o konjaniku Augustinu Stomiću, Karlovu sinu, popisanome u satniji drugoga pukovnika (colonnello in secondo) Marka Medina (pukovnija Antuna Medina) u Grčkoj (Romania) od 1703. do 1705. godine.

12 Crnokosi su bili konjanici Augustin Stomić (pukovnija Antuna Medina, 1703. - 1705.) i Matija Bartolov Fališić (pukovnija Luje Detrika, 1724. - 1734.). Opisom sjedokos označen je dobno (60 godina) stariji konjanik Ivan Panasović, sin Ivana Krstitelja, djelatan 1729. godine u osobnoj satniji pukovnika Nikole Divnića. 
pisivači učestalo bilježili boju konja koje su pojedini vojnici zaduživali (vidi: Grafikon 3). U primjeru ovdje obrađivanih Splićana najčešće su to dorati (bai, baio: 53,66 \%) i vranci (mor, moro: 29,27 \%), dočim su čilaši (leard, leardo) i riđani (saur, sauro) spomenuti s 9,76\% odnosno 7,32 \%). Zanimljivo je spomenuti kako su neki vojnici, mahom oni djelatni više godina i desetljeća, tijekom svoje karijere mijenjali konje. Takav je primjer Stjepan Matijin Dujmović, koji je u razdoblju od 1724. do 1763. djelovao u pukovnijama Luje Detrika i Franje Buća te isprva zaduživao dorata (1724. - 1734.), a potom (zabilježeno od 1750. godine) vranca; zatim Antun Ivanov Panasović, pripadnik pukovnija Šimuna Benje i Franje Buće od 1754. do 1773. godine, koji je pretežito jahao vranca, ali je 1758. kao njegov konj zabilježen riđan te Frane Ivanov Stuari, zadužen za vranca (1760. - 1763., pukovnija Franje Buća) i dorata (1785., pukovnija Tripuna Gregorine).

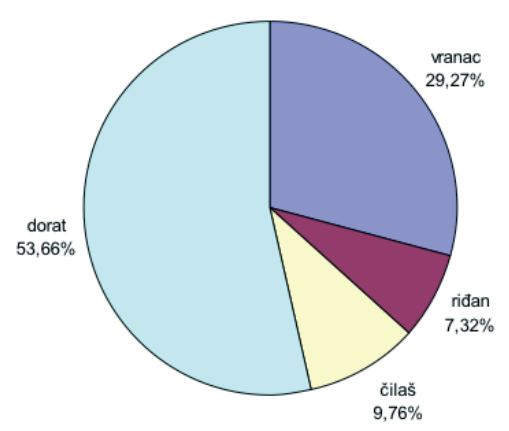

Grafikon 3. Boja konja koje su zaduživali konjanici iz Splita

Satnije pojedinih mletačkih pješačkih i konjaničkih pukovnija bile su tijekom 18. stoljeća, a osobito nakon okončanja posljednjega mletačko-osmanskog rata, stacionirane u glavnim vojnim uporišnim točkama Serenissime. To su gradovi-utvrde duž mletačkoga kopnenog posjeda diljem Veneta odnosno terraferme (Mleci - Lido, Padova, Treviso, Palmanova, Verona, Bergamo, Udine i druga), vodeća uporišta duž istočnoga Jadrana (Zadar, Split, Kotor) te nakon Požarevačkoga mira 1718. godine preostale mletačke stečevine u grčkome arhipelagu. Jedinice su, kako vrela svjedoče, bile vrlo mobilne te se pojedine satnije unutar malenoga broja godina bilježe na raznim lokacijama. Statistički promatrano (vidi: Grafikon 4), splitski se konjanici odnosno njihove postrojbe najčešće bilježe na području Veneta - u Mlecima i duž mletačkih gradova diljem terraferme $(68,75 \%$ u omjeru svih spomenutih mjesta popisivanja satnija i pukovnija). Unutar toga područja prevagu imaju Mleci (tamošnja vojna baza na Lidu zborno mjesto unovačenih vojnika odakle su se pojedine postrojbe upućivale na vršenje vojne službe), Brescia i Verona, a osim navedenih gradova na području Veneta kao 
mjesta stacioniranja postrojbi u kojima su djelovali splitski Croati a cavallo učestalije su zabilježeni Padova, Palmanova, Udine i Treviso. Kao manje učestalo mjesto popisivanja ovdje analiziranih Splićana spominju se još i Cremona i Rovigo. Dalmatinski su gradovi i utvrde u postotnome omjeru djelovanja splitskih vojnika zastupljeni s 23,21 \%. Prednjači Zadar - onovremena prijestolnica Dalmacije i najvažnije strateško mletačko uporište na istočnome Jadranu, ${ }^{13}$ dočim se od drugih gradova i utvrda bilježi još samo Split. Kada je riječ o Boki, splitski su vojnici zabilježeni isključivo u Kotoru (5,36 \%), glavnome gradu mletačke pokrajine (Albania Veneta), koji je tijekom 18. stoljeća predstavljao vodeću mletačku obrambenu utvrdu prema osmanskim posjedima u neposrednome zaleđu toga dijela Jadrana. Naposljetku, konjanici iz Splita u nekoliko su primjera zabilježeni na području mletačkih stečevina u Grčkoj (2,68 \%).

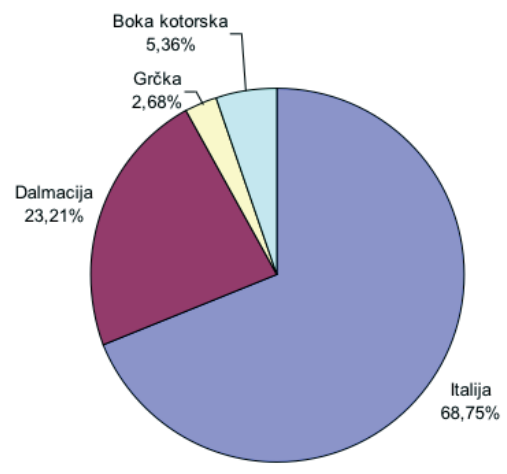

Grafikon 4. Područja djelovanja (popisivanja) satnija u kojima su zabilježeni konjanici iz Splita

U završnome dijelu rada ukratko ćemo se osvrnuti na vojne zapovjednike (pukovnike) unutar čijih su satnija djelovali Splićani. Takvi nam podaci otkrivaju niz imena zapaženih onovremenih mletačkih časnika zavičajem s istočne obale Jadrana. Neki od njih isprva se spominju kao kapetani satnija, s vremenom bivaju promaknuti u pukovnike, a neki u završnoj etapi vojne karijere postaju generali. Navođenje njihovih imena svojevrstan je pregled istaknutih hrvatskih časnika koji su pod stijegom Privedre Republike dosegnuli svoja najveća postignuća. Stoga ćemo radi boljega razumijevanja konteksta djelovanja Splićana u mletačkome konjaništvu osnovne podatke navesti podrobnije. Po važnosti se izdvajaju Zadrani, mahom odvjetci tamošnjih uglednih i drevnih plemićkih obitelji. To su pukovnik Lujo Detriko (1670. - 1749.), posljednji muški potomak srednjovjekovne zadarske plemićke obitelji, istaknuti sudionik Morejskoga rata u Dalmaciji i diljem današnjega Crnogorskog primorja te na

13 Uz Zadar se povremeno kao mjesto popisivanja spominje i Sutomišćica na otoku Ugljanu. 
kraju karijere obnašatelj generalskoga čina. ${ }^{14}$ Zadarski je plemić bio i Šimun Nassi, sudionik Morejskoga rata i Drugoga morejskog rata od 1714. do 1718. godine te od 1713. godine pukovnik u Cavalleria Croati, ${ }^{15}$ dočim su iz obitelji Benja tri odvjetka (Franjo, Lujo Karlo i Šimun) zabilježena u najvišim časničkim činovima hrvatske konjice. ${ }^{16}$ Važnu ulogu u konjaničkim snagama imali su i šibenski plemić Nikola Divnićc ${ }^{17}$ kao i trogirski plemići Juraj Radoš (oko 1661. - 1731.; pukovnik od 1719. godine) ${ }^{18}$ i Antun Radnić (djelatan u činu pukovnika koncem 18. stoljeća). ${ }^{19}$ Hrvatskim konjaničkim pukovnijama zapovijedali su - uz Dalmatince - i časnici zavičajem iz Boke. Splitski se vojnici tako bilježe u sastavu pukovnije uglednoga kotorskoga plemića Franje Buće $e^{20}$ kao i u pukovniji Tripuna Gregorine. ${ }^{21}$ Naposljetku, s Paštrovićeva područja potjecao je Antun Medin, zapovjednik konjaničkih postrojbi u kojima su djelovali Splićani na samome početku 18. stoljeća. ${ }^{22}$

14 O Luji Detriku podrobnije vidi u: Lovorka Čoralić, “Zadarski patricij Lujo Detriko (1672. - 1749.) - zapovjednik hrvatske konjice (Cavalleria Croati)", Zbornik Odsjeka za povijesne znanosti Zavoda za povijesne i društvene znanosti HAZU 32 (2014): 99-129. Gradivo o njegovu djelovanju u činu pukovnika pohranjeno je u: RI-ASVe-0715-Inquisitori ... pubblici ruoli, Cavalleria Croati, b. 801-806.

15 O Šimunu Nassiju podrobnije vidi u: Lovorka Čoralić, “Zadarski patricij Šimun Nassi - pukovnik hrvatskih konjanika u mletačkoj vojsci (početak 18. stoljeća)”, Povijesni zbornik - godišnjak za kulturu i povijesno naslijeđe 4 (2017), br. 5: 7-31. Gradivo o njegovu djelovanju u činu pukovnika pohranjeno je u: RI-ASVe- 0715-Inquisitori ... pubblici ruoli, Cavalleria Croati, b. 824-825.

16 Franjo i Lujo Karlo Benja bilježe se kao bojnici od dvadesetih godina 18. stoljeća. Gradivo o njihovu djelovanju u činu pukovnika (sredina 18. stoljeća) pohranjeno je u: RI-ASVe-0715-Inquisitori ... pubblici ruoli, Cavalleria Croati, b. 774-775. Gradivo o djelovanju Šimuna Benje u činu pukovnika (sedamdesete i osamdesete godine 18. stoljeća) pohranjeno je u istome arhivskom fondu, b. 770, 776 781.

17 O Nikoli Divniću podrobnije vidi u: Lovorka Čoralić, “Šibenski plemić Nikola Divnić (1654. 1734.) - pukovnik hrvatske lake konjice (Cavalleria Croati)", Radovi Zavoda za povijesne znanosti HAZU u Zadru 54 (2012): 125-145. Gradivo o njegovu djelovanju u činu pukovnika pohranjeno je u: RI-ASVe-0715-Inquisitori ... pubblici ruoli, Cavalleria Croati, b. 807-809.

18 Gradivo o djelovanju Jurja Radoša u činu pukovnika pohranjeno je u: RI-ASVe-0715-Inquisitori ... pubblici ruoli, Cavalleria Croati, b. 826.

19 Gradivo o djelovanju Antuna Radnića u činu pukovnika pohranjeno je u: RI-ASVe-0715-Inquisitori ... pubblici ruoli, Cavalleria Croati, b. 826.

20 Franjo Buća je koncem karijere bio bojnik vojske i glavni zapovjednik odnosno nadintendant hrvatskoga konjaništva (sargente maggiore di battaglia e sopraintendante alla Cavalleria). Gradivo o njegovu djelovanju u činu pukovnika (od sredine 18. stoljeća do oko 1775. godine) pohranjeno je u: RI-ASVe-0715-Inquisitori ... pubblici ruoli, Cavalleria Croati, b. 782-786.

21 O Tripunu Gregorini podrobnije vidi u: Lovorka Čoralić, Maja Katušić, "Kotoranin Tripun Gregorina (1719-1791) - pukovnik hrvatskih konjanika (Croati a cavallo)", Anali Zavoda za povijesne znanosti HAZU u Dubrovniku 55 (2017), br. 2: 375-406. Gradivo o njegovu djelovanju u činu pukovnika pohranjeno je u: RI-ASVe-0715-Inquisitori ... pubblici ruoli, Cavalleria Croati, b. 815-820.

22 Gradivo o djelovanju Antuna Medina u činu pukovnika pohranjeno je u: RI-ASVe-0715-Inquisitori ... pubblici ruoli, Cavalleria Croati, b. 821-823. 


\section{Zaključak}

Vojna je povijest zasigurno predstavljala jednu od izrazito važnih sastavnica tijekom višestoljetnih hrvatsko-mletačkih odnosa. Istraživanje ove problematike pobuđivalo je, a i danas pobuđuje, interes niza znanstvenika kako hrvatske historiografije, tako i historiografije drugih zemalja. Kandijski, Morejski i Drugi morejski rat odvijali su velikim dijelom duž širokoga poteza istočnojadranske obale, a prevažan dio u mletačkim vojnim snagama imale su pješačke i konjaničke postrojbe (Fanti oltramarini, Croati a cavallo ili Cavalleria Croati), koje su ponajprije bile novačene duž hrvatskoga etničkog prostora. Istraživanje regionalnih skupina (prema krajevima ili gradovima) pripadnika pojedinih postrojbi stoga držimo da je važan dio upoznavanja širega konteksta hrvatske kao i mletačke vojne povijesti u ranome novom vijeku. U ovome radu težište istraživanja bilo je usmjereno na Splićane - vojnike u elitnoj mletačkoj postrojbi Croati a cavallo. Na osnovi podrobnoga proučavanja spisa iz Državnoga arhiva u Mlecima (fond: Inquisitori sopra l'amministrazione dei pubblici ruoli) razvidno je da su Splićani činili tijekom 18. stoljeća (razdoblja na koje je, zbog očuvanosti izvora, fokusiran ovaj rad) činili - uz Zadrane, Šibenčane, Trogirane i Bokelje - izrazito važnu vojničku skupinu. Njihova se prisutnost u mletačkome konjaništvu opaža kroz cijelo stoljeće, a mjesta njihova djelovanja (stacioniranja, popisivanja) odražavaju rasprostranjenost mletačkih stečevina od terraferme, preko Dalmacije i Boke kotorske do Grčke, ali i posvjedočuju o mobilnosti elitnih mletačkih kopnenih jedinica. Nadalje, splitski su se konjanici, promatrajući ih u kontekstu cjelovitoga uzorka hrvatskih vojnika u rečenim kopnenim snagama Serenissime, uklapali u opću sliku vojnika toga vremena. Oni su najčešće bili srednjega rasta, smeđokosi ili crnokosi, a prosječna životna dob u kojoj su zabilježeni u izvoru iznosila je 34 godine. Njima su zapovijedali visoki časnici zavičajem iz niza gradova Stato da Mar od Zadra do Kotora. Popisi vojnika otkrivaju nam, nadalje, isječke iz vojne karijere odvjetaka pojedinih obitelji, duljinu njihove vojne službe, napredovanje u karijeri kao i cijeli niz prezimena koja, vjerujemo, mogu biti zanimljiv izvor za proučavanje onovremene splitske onomastike. Naposljetku možemo zaključiti kako je istraživanje udjela Hrvata (kao i pripadnika drugih nacionalnih skupina) - svrstanih unutar pojedinih regija, gradova i manjih naselja - otvorena tema koja iziskuje dodatna istraživačka pregnuća i rad na novim dokumentima, prvenstveno pohranjenima u Archivio di Stato di Venezia i Državnome arhivu u Zadru. Stoga vjerujemo da će se, kako se bude povećavao opseg i raznovrsnost korištenoga arhivskog gradiva, spoznaje o ovdje navedenim i prezentiranim splitskim vojnicima u mletačkim kopnenim postrojbama bitno proširiti novim i višestruko korisnim spoznajama. 


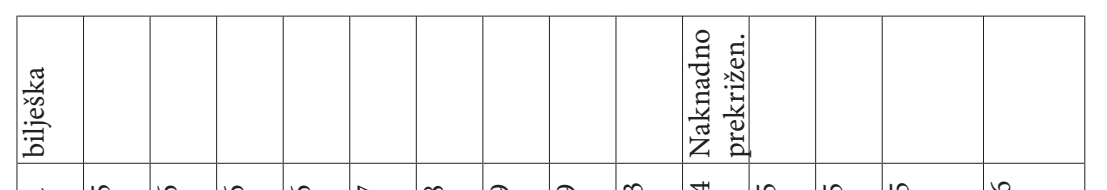

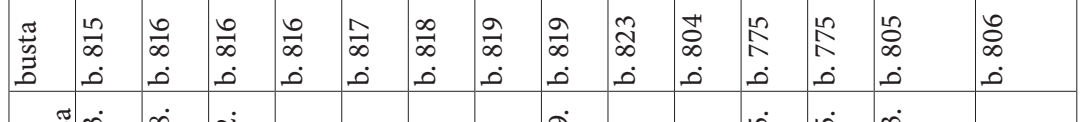

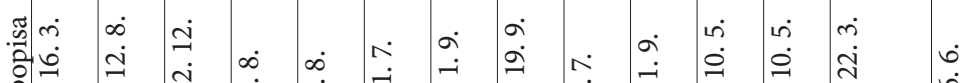

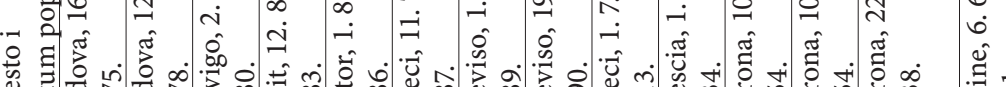

$\approx$ थ

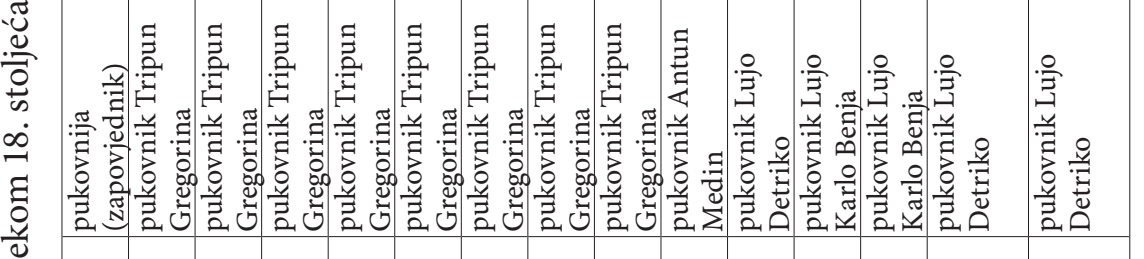

$\stackrel{\Xi}{\rightleftarrows}$

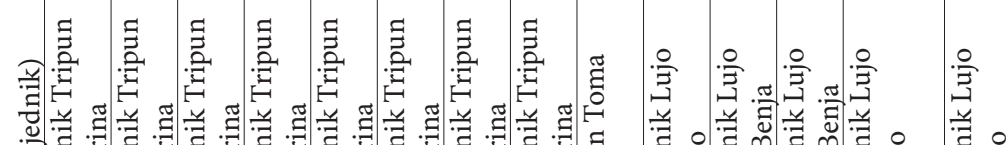

तิ

寻

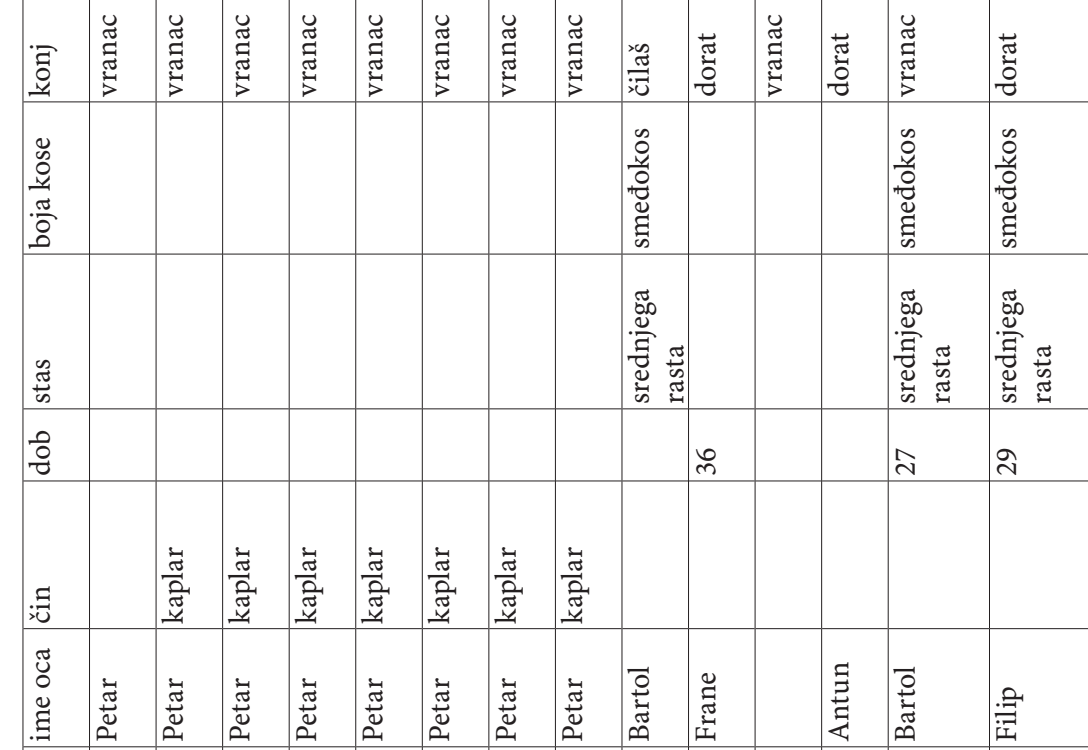

푝

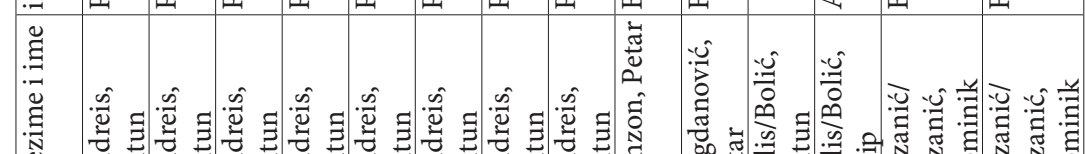

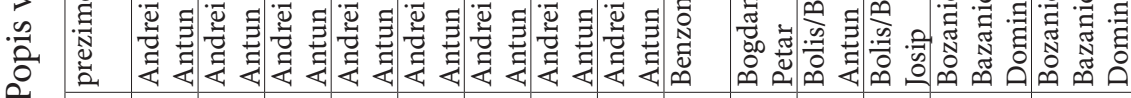

芯

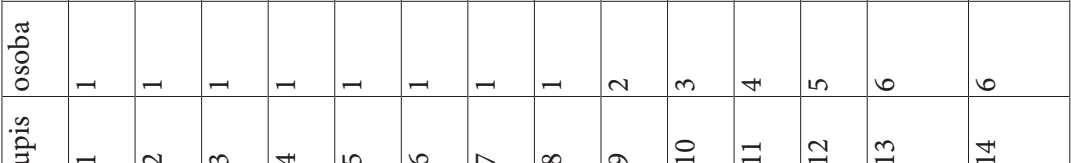

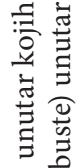

용

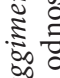

$\stackrel{\pi}{\frac{\pi}{7}}$

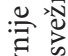

高

$\stackrel{\pi}{\circ}$

:

क.

원.

:

苞

के

चี

焉:

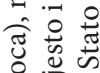

무

छ

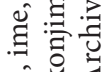

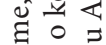

牙 $\overline{0}$

능

亲岛

용

政

क्ष

요유.

घี

实

部

寻泀

ठ

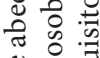

苍洁忐

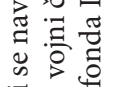

चี ज्ञ

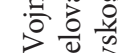




\begin{tabular}{|c|c|c|c|c|c|c|c|c|c|c|c|c|c|c|c|c|c|c|}
\hline & & & & & & & & & & & 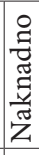 & & & & & & & \\
\hline ט & $\begin{array}{l}\infty \\
\infty \\
\infty \\
\dot{0}\end{array}$ & $\begin{array}{l}\vec{\sigma} \\
\infty \\
\dot{0}\end{array}$ & $\begin{array}{l}\infty \\
\infty \\
\dot{0} \\
\dot{0}\end{array}$ & $\begin{array}{l}\stackrel{0}{\infty} \\
\dot{0}\end{array}$ & $\begin{array}{l}0 \\
\infty \\
\dot{0}\end{array}$ & $\begin{array}{l}\vec{y} \\
\infty \\
\dot{0}\end{array}$ & $\begin{array}{l}\stackrel{8}{1} \\
\infty \\
\dot{0}\end{array}$ & $\begin{array}{l}10 \\
\infty \\
\dot{0} \\
\end{array}$ & $\begin{array}{l}\tilde{N} \\
\infty \\
\vdots \\
\dot{0}\end{array}$ & 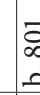 & $\begin{array}{l}\text { Oे } \\
\infty \\
\dot{0}\end{array}$ & $\begin{array}{l}\vec{b} \\
\infty \\
0\end{array}$ & $\begin{array}{l}\text { Oे } \\
\infty \\
\dot{0}\end{array}$ & $\begin{array}{l}\widetilde{\sigma} \\
\infty \\
\vdots \\
.\end{array}$ & $\begin{array}{l}+4 \\
0 \\
0 \\
0\end{array}$ & $\begin{array}{l}\frac{N}{N} \\
\dot{0}\end{array}$ & 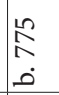 & \\
\hline $\begin{array}{l}\tilde{Z} \\
\tilde{\Xi}\end{array}$ & 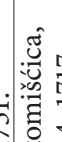 & 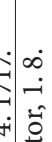 & $\therefore$ & $\begin{array}{l}\dot{\alpha} \\
\dot{1} \\
\hat{0}\end{array}$ & $\begin{array}{l}0 \\
2 \\
0 \\
0 \\
0 \\
\frac{0}{2}\end{array}$ & $\begin{array}{l}\infty \\
-1\end{array}$ & $\begin{array}{l}0 \\
\dot{-} \\
\dot{0}\end{array}$ & $\begin{array}{l}\dot{n} \\
\dot{0} \\
\stackrel{1}{*}\end{array}$ & 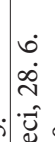 & 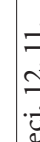 & $\begin{array}{l}\dot{0} \\
\text { in } \\
\approx\end{array}$ & $\begin{array}{l}\dot{Z} \\
\stackrel{i}{\beth}\end{array}$ & $\begin{array}{l}0 \\
\dot{10} \\
\tilde{\sigma}\end{array}$ & 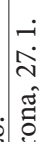 & 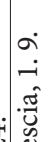 & 列 & 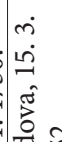 & \\
\hline
\end{tabular}

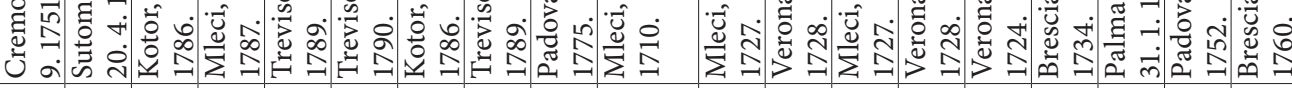

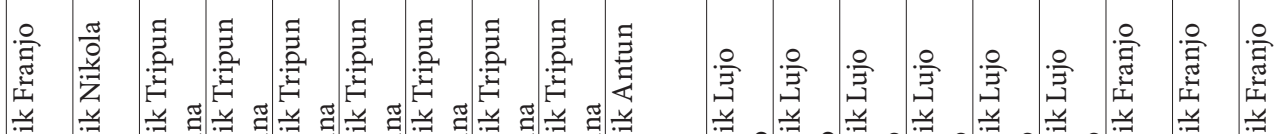

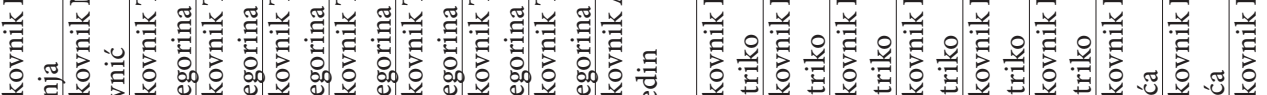

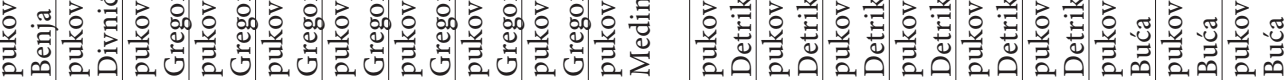

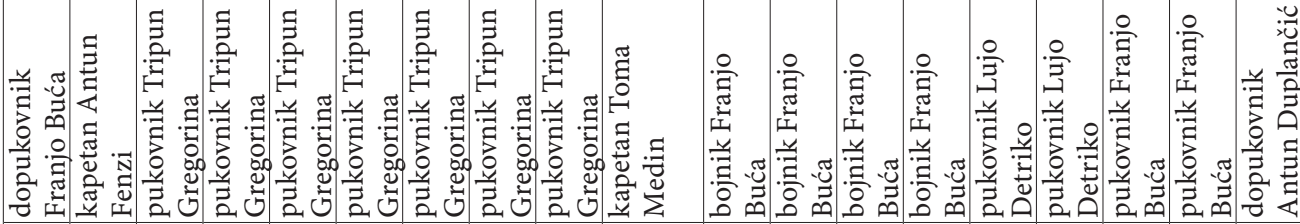

\begin{tabular}{|c|c|c|c|c|c|c|c|c|c|c|c|c|c|c|c|c|c|c|}
\hline \multirow[t]{5}{*}{$\begin{array}{l}\vec{\sigma} \\
\overrightarrow{0} \\
\vec{\sigma}\end{array}$} & & 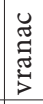 & 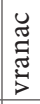 & 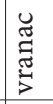 & 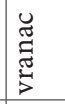 & 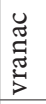 & 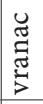 & 葱 & $\begin{array}{l}\overrightarrow{\tilde{J}} \\
\vec{\sigma}\end{array}$ & & & & $\begin{array}{l}\vec{\pi} \\
\overrightarrow{\tilde{\sigma}} \\
\overparen{\sigma}\end{array}$ & 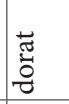 & $\begin{array}{l}\overrightarrow{\tilde{J}} \\
\overrightarrow{0} \\
\vec{b}\end{array}$ & 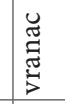 & 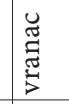 & 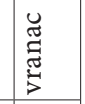 \\
\hline & & & & & & & & & 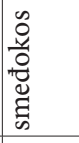 & & & & 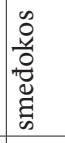 & & & & & \\
\hline & & & & & & & & & 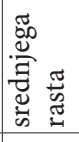 & & & & 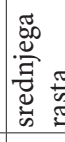 & & & & & \\
\hline & & & & & & & & & & & & & $\stackrel{\sim}{\sim}$ & & & & & \\
\hline & & 苂 & 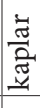 & 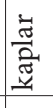 & 离 & & & 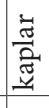 & & & & & & & & & & \\
\hline$\stackrel{\Xi}{\Xi}$ & 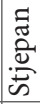 & 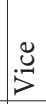 & $\stackrel{\mathscr{\Xi}}{\rightleftharpoons}$ & 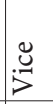 & $\stackrel{\ddot{\sim}}{\pi}$ & $\stackrel{\dddot{y}}{=}$ & 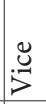 & 竧 & $\stackrel{\mathscr{\Xi}}{ }$ & こ & 气ี & 芯 & 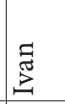 & 范 & : & 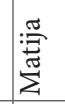 & : & : \\
\hline 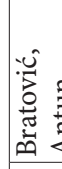 & 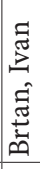 & نे & & ئ. & : & 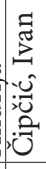 & 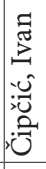 & 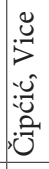 & 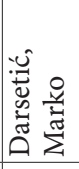 & 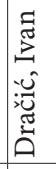 & 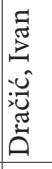 & 恣 & 点 & 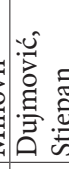 & 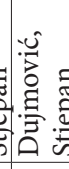 & 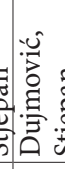 & 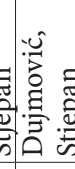 & 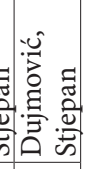 \\
\hline
\end{tabular}

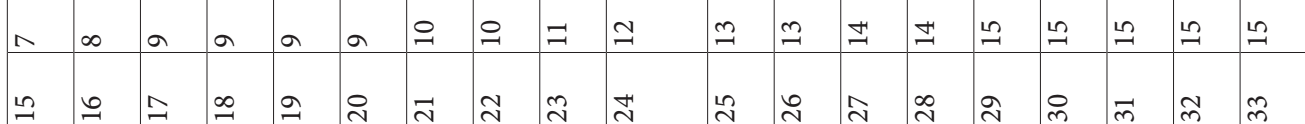




\begin{tabular}{|c|c|c|c|c|c|c|c|c|c|c|c|c|c|c|c|c|c|c|}
\hline 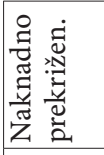 & & & & 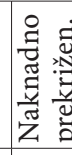 & & & & & & 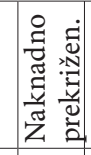 & & & & & & & & \\
\hline 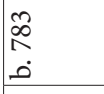 & $\begin{array}{l}\tilde{1} \\
\delta \\
0 \\
\dot{0}\end{array}$ & $\begin{array}{l}\text { H } \\
\infty \\
0 \\
0\end{array}$ & $\begin{array}{l}\tilde{N} \\
\infty \\
\dot{0} \\
\end{array}$ & $\begin{array}{l}\underset{J}{1} \\
\infty \\
\dot{0}\end{array}$ & $\begin{array}{l}\overrightarrow{8} \\
\dot{0} \\
\dot{0}\end{array}$ & $\begin{array}{l}\stackrel{5}{\AA} \\
\vdots \\
\end{array}$ & $\begin{array}{l}\stackrel{n}{N} \\
\dot{0} \\
\end{array}$ & $\begin{array}{l}\dot{\mathscr{N}} \\
\infty \\
\dot{0} \\
\end{array}$ & $\begin{array}{l}\dot{0} \\
\infty \\
\dot{0} \\
\dot{0}\end{array}$ & $\begin{array}{l}0 \\
\dot{\partial} \\
0 \\
\dot{0}\end{array}$ & $\begin{array}{l}\infty \\
0 \\
\infty \\
0 \\
0\end{array}$ & $\begin{array}{l}\infty \\
\infty \\
\infty \\
0\end{array}$ & $\begin{array}{l}\infty \\
\infty \\
\infty \\
\dot{0} \\
\dot{0}\end{array}$ & $\begin{array}{l}\stackrel{n}{\curvearrowright} \\
\stackrel{0}{0} \\
\end{array}$ & $\begin{array}{l}\stackrel{n}{n} \\
\stackrel{1}{n} \\
\vdots\end{array}$ & $\begin{array}{l}0 \\
\infty \\
\infty \\
\dot{0}\end{array}$ & $\begin{array}{l}0 \\
\infty \\
0 \\
\dot{0}\end{array}$ & $\begin{array}{l}n \\
\infty \\
\dot{0} \\
\dot{0}\end{array}$ \\
\hline 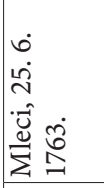 & 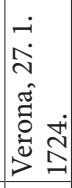 & 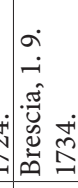 & 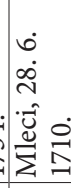 & 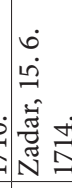 & 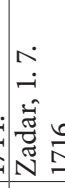 & 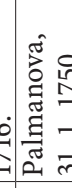 & 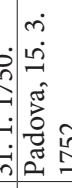 & 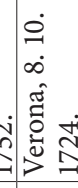 & 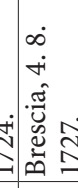 & 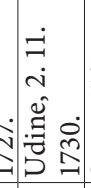 & 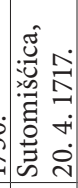 & 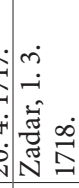 & 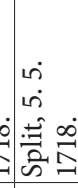 & 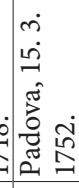 & 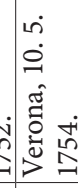 & 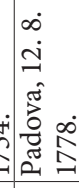 & 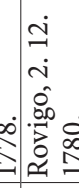 & 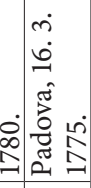 \\
\hline 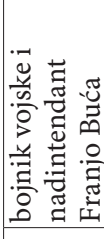 & 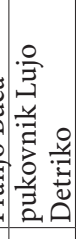 & 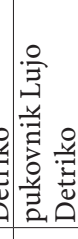 & 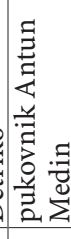 & 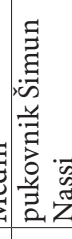 & 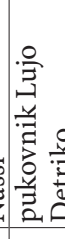 & 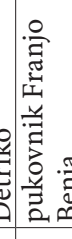 & 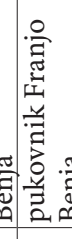 & 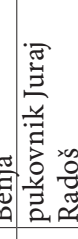 & 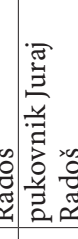 & 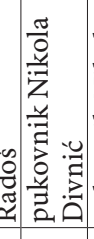 & 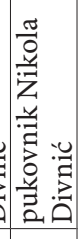 & 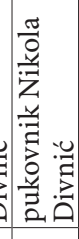 & 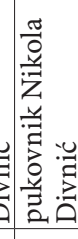 & 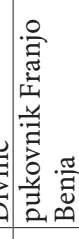 & 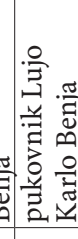 & 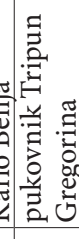 & 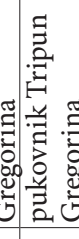 & 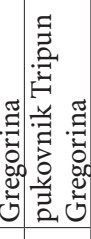 \\
\hline 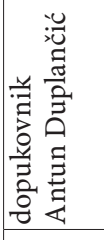 & 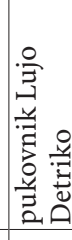 & 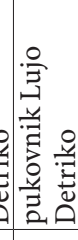 & 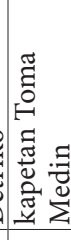 & 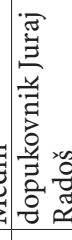 & 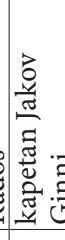 & 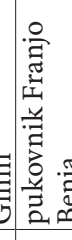 & 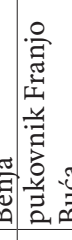 & 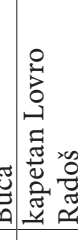 & 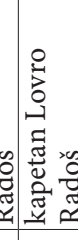 & 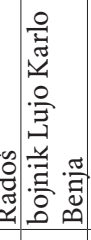 & 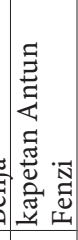 & 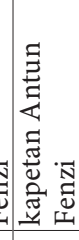 & 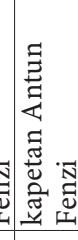 & 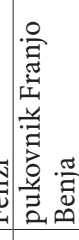 & 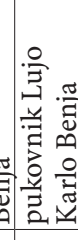 & 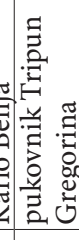 & 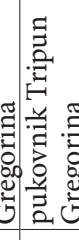 & 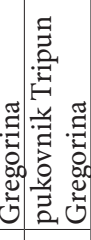 \\
\hline 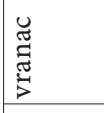 & 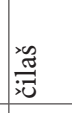 & $\begin{array}{l}\frac{x}{\pi} \\
\frac{\pi}{\pi y}\end{array}$ & 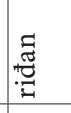 & & 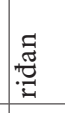 & $\begin{array}{l}\vec{\pi} \\
\text { to } \\
\end{array}$ & $\begin{array}{l}\overrightarrow{\tilde{a}} \\
\vec{\sigma} \\
\vec{\theta}\end{array}$ & & & 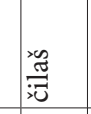 & & & & 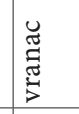 & 节 & $\begin{array}{l}\vec{\pi} \\
\vec{\sigma} \\
\vec{\sigma}\end{array}$ & $\begin{array}{l}\vec{\pi} \\
\text { tै } \\
\end{array}$ & 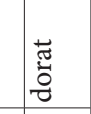 \\
\hline & 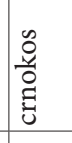 & 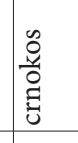 & 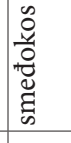 & & & & & & & 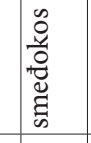 & & & & & & & & \\
\hline & 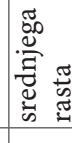 & 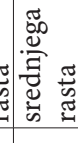 & 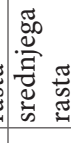 & & & & & & & 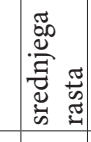 & & & & & & & & \\
\hline & $\stackrel{\leftrightarrow}{4}$ & & & & & & & & & లి & & & & & & & & \\
\hline 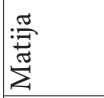 & $\vec{P}$ & 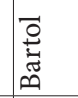 & 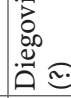 & 旁 & $\frac{\tilde{J}}{\tilde{\omega}}$ & 苂 & $\stackrel{\Xi}{\Xi}$ & 宽 & 胥 & 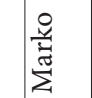 & 胥 & 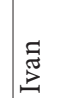 & 宽 & 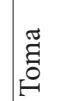 & 蚫 & 芠 & 胥 & $\stackrel{\Xi}{\Xi}$ \\
\hline 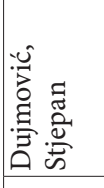 & 芯 & 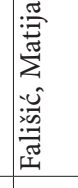 & 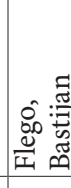 & 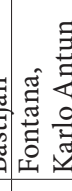 & 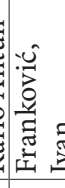 & 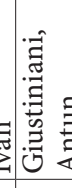 & 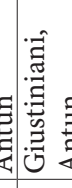 & 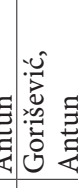 & 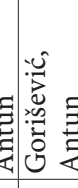 & 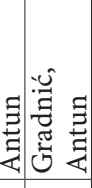 & 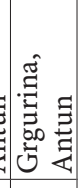 & 结 & 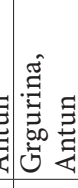 & 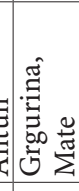 & 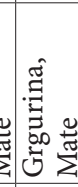 & 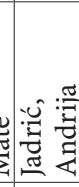 & 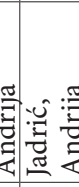 & 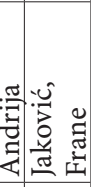 \\
\hline 2 & $\stackrel{-}{\circ}$ & $\stackrel{\bullet}{\circ}$ & $\triangleq$ & $\stackrel{\infty}{=}$ & 2 & iิ & নి & $\vec{\sim}$ & $\vec{\sim}$ & $\tilde{N}$ & $\approx$ & $\ddot{\sim}$ & $\tilde{\sim}$ & $\underset{\sim}{\sim}$ & $\stackrel{\mathbb{N}}{\mathbf{N}}$ & $\stackrel{2}{\sim}$ & $\stackrel{2}{\sim}$ & $\stackrel{\sim}{2}$ \\
\hline$m$ & $m$ & li & $\hat{m}$ & $\infty$ & ले & 아 & $F$ & f & f & 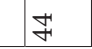 & 19 & Lot & f & $\stackrel{\infty}{\infty}$ & f & in & in & in \\
\hline
\end{tabular}




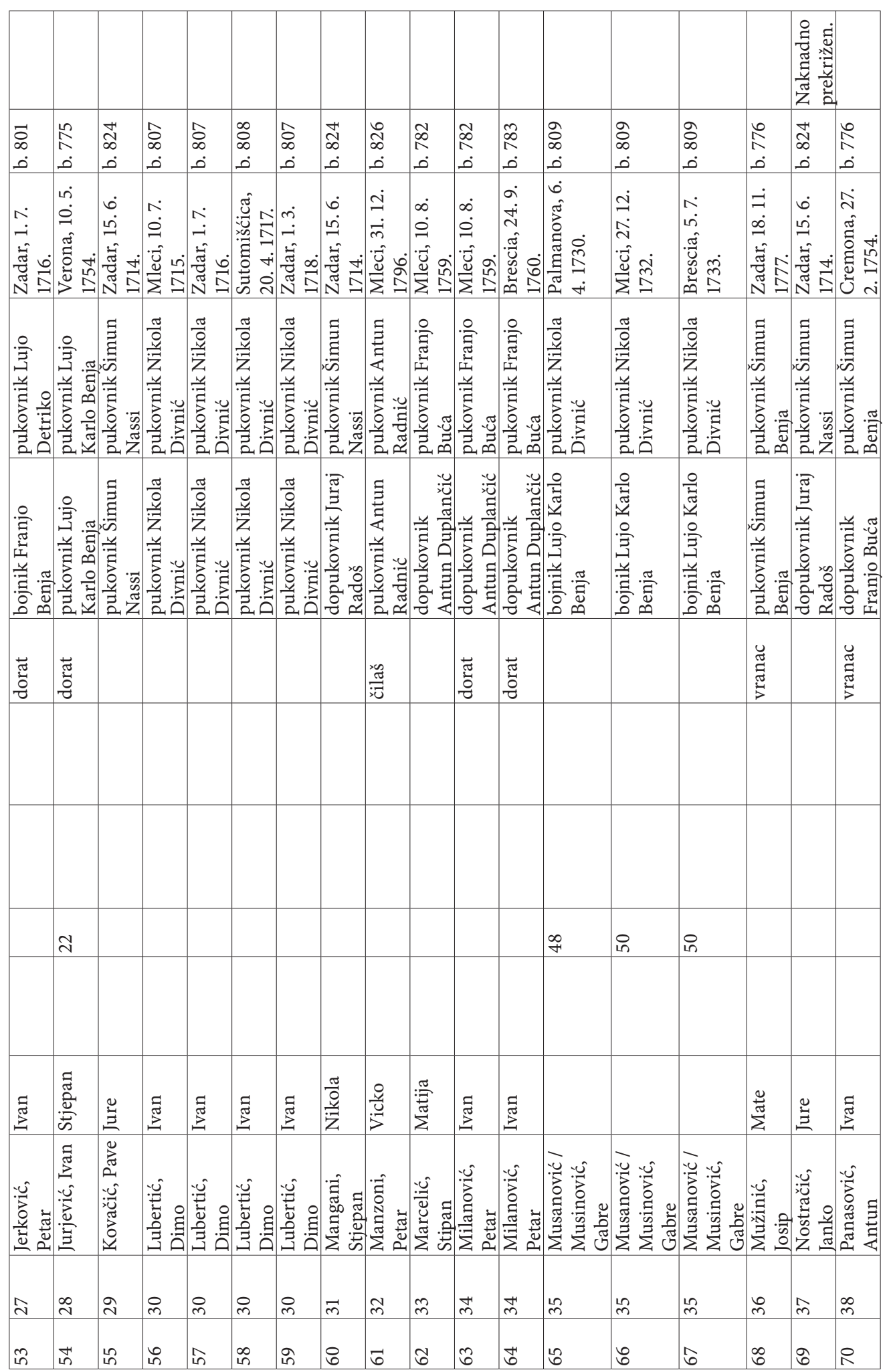




\begin{tabular}{|c|c|c|c|c|c|c|c|c|c|c|c|c|c|c|c|c|}
\hline & & & & & & & & & & & 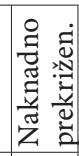 & 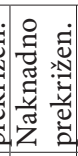 & & & & \\
\hline $\begin{array}{l}\infty \\
\infty \\
\infty \\
\dot{0}\end{array}$ & $\begin{array}{l}\infty \\
\infty \\
0 \\
0 \\
0\end{array}$ & $\begin{array}{l}\infty \\
\infty \\
0 \\
\dot{0}\end{array}$ & 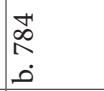 & 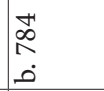 & $\begin{array}{l}\not \\
\infty \\
0 \\
0 \\
0\end{array}$ & \begin{tabular}{l}
$\infty$ \\
\hdashline \\
\hdashline \\
0
\end{tabular} & $\begin{array}{l}0 \\
\infty \\
\infty \\
\dot{0}\end{array}$ & $\begin{array}{l}\hat{\partial} \\
\infty \\
\dot{0}\end{array}$ & $\begin{array}{l}\vec{D} \\
\infty \\
\dot{0}\end{array}$ & $\begin{array}{l}\hat{0} \\
\infty \\
0\end{array}$ & $\begin{array}{c}\infty \\
\stackrel{\infty}{1} \\
\vdots \\
0\end{array}$ & $\begin{array}{c}\infty \\
⿱ ⺊ \\
1 \\
0 \\
0\end{array}$ & $\begin{array}{l}\overrightarrow{0} \\
\infty \\
\dot{0}\end{array}$ & $\begin{array}{l}\tilde{\partial} \\
\infty \\
0 \\
\dot{0}\end{array}$ & $\begin{array}{l}\tilde{\partial} \\
\infty \\
\dot{0} \\
\dot{0}\end{array}$ & $\begin{array}{l}\vec{H} \\
0 \\
\dot{0} \\
\dot{0}\end{array}$ \\
\hline 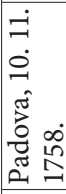 & 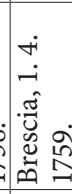 & 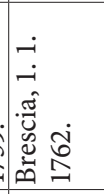 & 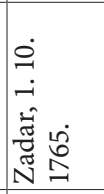 & 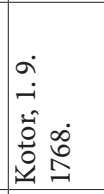 & 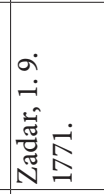 & 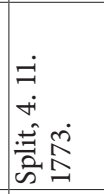 & 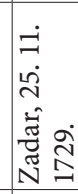 & 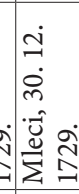 & 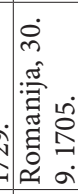 & 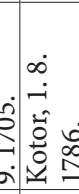 & 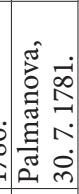 & 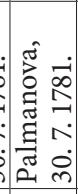 & \begin{tabular}{l}
$\infty$ \\
$\infty$ \\
$\infty$ \\
$\vdots$ \\
$\vdots$ \\
\hdashline \\
\hdashline
\end{tabular} & 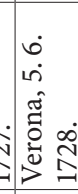 & 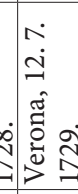 & 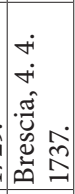 \\
\hline 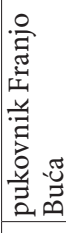 & 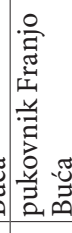 & 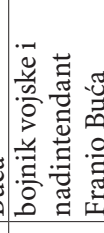 & 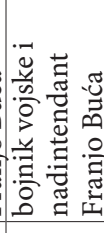 & 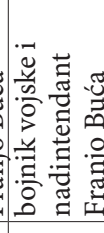 & 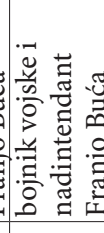 & 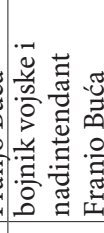 & 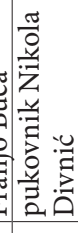 & 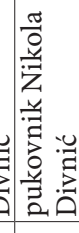 & 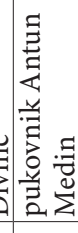 & 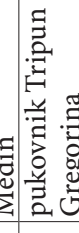 & 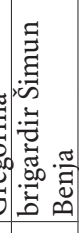 & 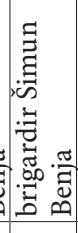 & 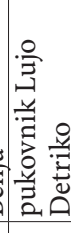 & 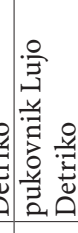 & 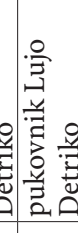 & 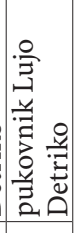 \\
\hline 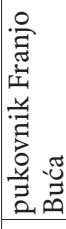 & 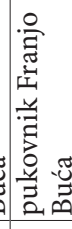 & 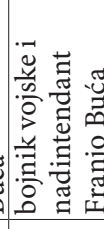 & 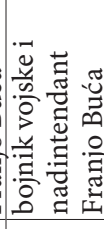 & 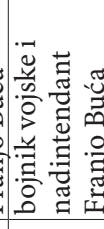 & 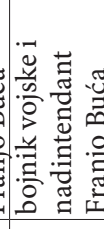 & 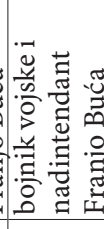 & 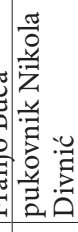 & 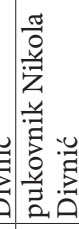 & 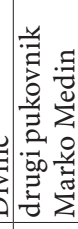 & 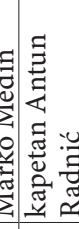 & 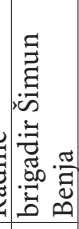 & 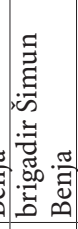 & 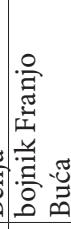 & 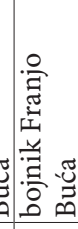 & 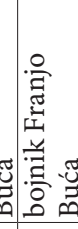 & 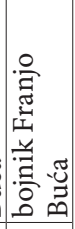 \\
\hline 毒 & 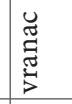 & $\begin{array}{l}\text { U } \\
\text { İ } \\
\text { 今 }\end{array}$ & 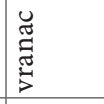 & 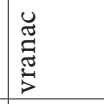 & 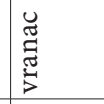 & $\begin{array}{l}\mathscr{\Xi} \\
\underset{\pi}{\tilde{\Xi}} \\
\text { J }\end{array}$ & & & 莺 & 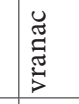 & 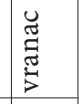 & & t) & 莒 & 芴 & $\begin{array}{l}\vec{\pi} \\
\text { t] } \\
\theta\end{array}$ \\
\hline & & & & & & & 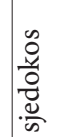 & 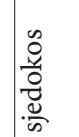 & 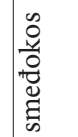 & & & & 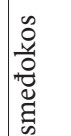 & 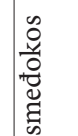 & 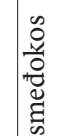 & 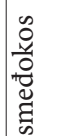 \\
\hline & & 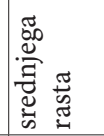 & 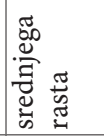 & 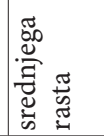 & 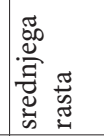 & & & & 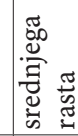 & & & & 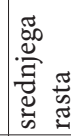 & 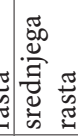 & 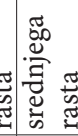 & 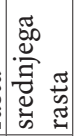 \\
\hline & & & & & & & 8 & 8 & & & & & $\stackrel{\sim}{\sim}$ & 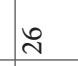 & $\hat{\lambda}$ & \\
\hline 芯 & 胥 & 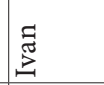 & Еี & 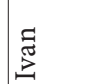 & 疍 & 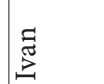 & 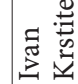 & 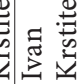 & 苞 & $\mid \frac{8}{\bar{z}}$ & $\frac{\tilde{\pi}}{\tilde{\omega}}$ & 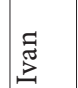 & 营 & 苞 & 泀 & 苟 \\
\hline 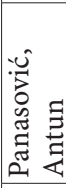 & 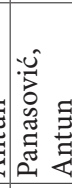 & 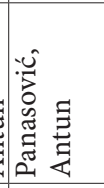 & 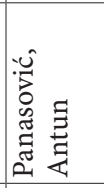 & 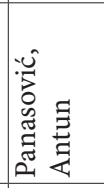 & 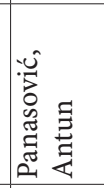 & 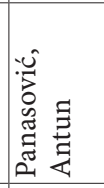 & 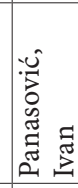 & 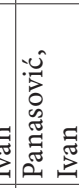 & 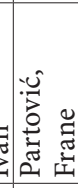 & 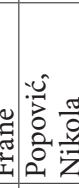 & 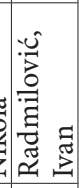 & 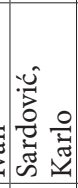 & 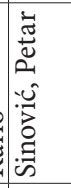 & 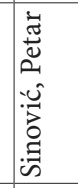 & 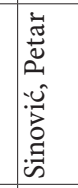 & 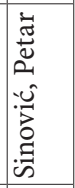 \\
\hline$\stackrel{\infty}{\infty}$ & $\prod_{\infty}^{\infty}$ & $\stackrel{\infty}{\infty}$ & $\stackrel{\infty}{\infty}$ & $\infty$ & $\infty$ & $\stackrel{\infty}{\infty}$ & ले & ले & 아 & $F$ & F & $\mathscr{F}$ & $\not{H}$ & F & F & F \\
\hline 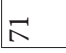 & $\mathbb{N}$ & $\cong$ & 年 & 隹 & $\mathbb{R}$ & $\lesssim$ & $\stackrel{\infty}{\wedge}$ & i & $\infty$ & $\infty$ & $\infty$ & $\infty$ & \$ & $\infty$ & $\infty$ & $1 \infty$ \\
\hline
\end{tabular}




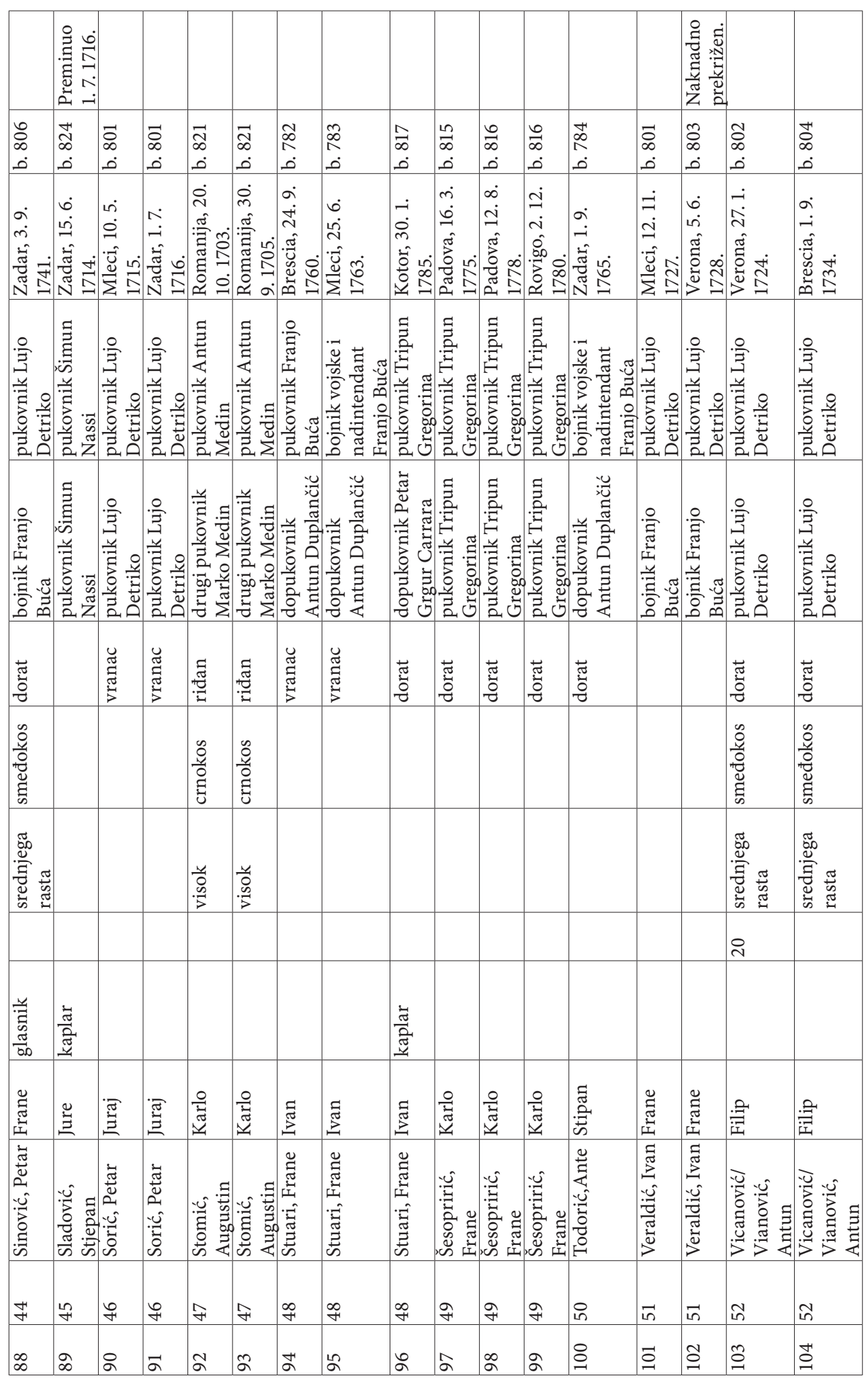




\begin{tabular}{|c|c|c|c|c|c|c|c|c|}
\hline $\begin{array}{l}0 \\
\infty \\
\infty \\
0 \\
0\end{array}$ & $\begin{array}{l}8 \\
\infty \\
\infty \\
\end{array}$ & $\begin{array}{l}\widetilde{1} \\
\delta \\
0 \\
\dot{0}\end{array}$ & $\begin{array}{l}\text { ठ́ } \\
\infty \\
\dot{0} \\
\end{array}$ & $\begin{array}{l}2 \\
\infty \\
\infty \\
0 \\
0\end{array}$ & $\begin{array}{l}8 \\
\infty \\
0 \\
\end{array}$ & $\begin{array}{l}0 \\
0 \\
0 \\
0\end{array}$ & $\begin{array}{l}\stackrel{1}{1} \\
\infty \\
\dot{0} \\
\end{array}$ & $\begin{array}{l}\overrightarrow{8} \\
\infty \\
\dot{0}\end{array}$ \\
\hline 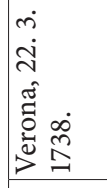 & 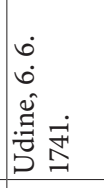 & 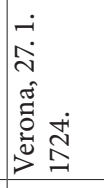 & 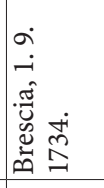 & 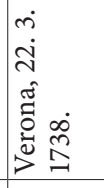 & 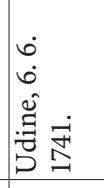 & 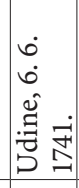 & 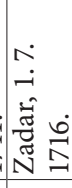 & 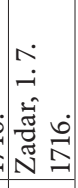 \\
\hline 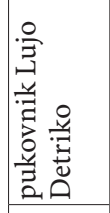 & 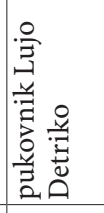 & 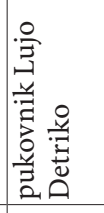 & 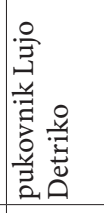 & 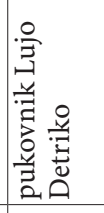 & 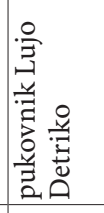 & 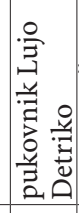 & 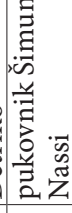 & 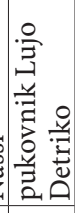 \\
\hline 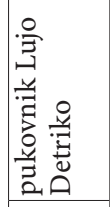 & 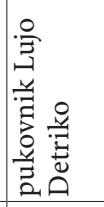 & 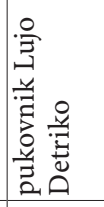 & 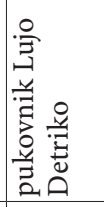 & 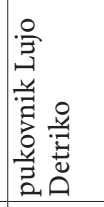 & 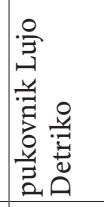 & 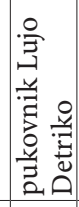 & 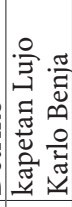 & 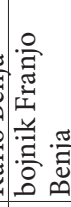 \\
\hline 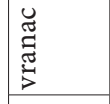 & 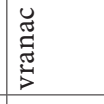 & 苛 & 苛 & $\begin{array}{l}\vec{\pi} \\
\overrightarrow{0} \\
\vec{\theta}\end{array}$ & 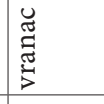 & 苛 & 苞 & 苛 \\
\hline 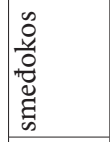 & 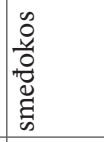 & 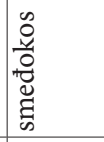 & 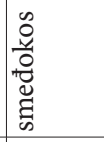 & 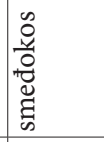 & 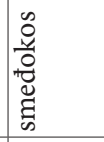 & 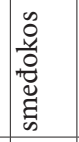 & & \\
\hline 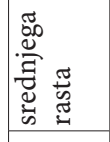 & 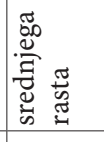 & 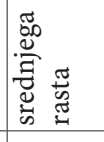 & 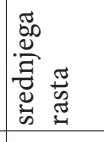 & 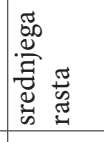 & 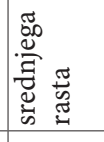 & 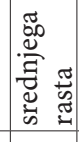 & & \\
\hline & & $\stackrel{\sim}{\sim}$ & & & & i & & \\
\hline & & & & & & $\begin{array}{l}\tilde{\Xi} \\
\overrightarrow{\tilde{z}} \\
\ddot{\varpi}\end{array}$ & & \\
\hline 害 & $\because$ & $\because$ 空 & $\because$ & $\because$ 空 & 空 & Е & 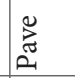 & 芯 \\
\hline 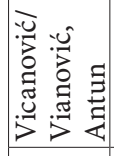 & 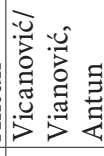 & 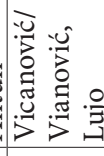 & 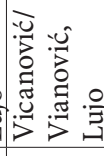 & 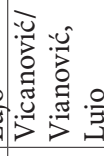 & 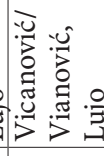 & 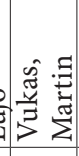 & $\begin{array}{ll}3 \\
\mathrm{~N}\end{array}$ & 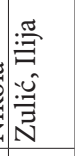 \\
\hline กิ & กิ & in & in & in & in & in & in & L \\
\hline$\stackrel{2}{\varrho}$ & 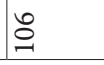 & 응 & $\stackrel{\infty}{\stackrel{0}{0}}$ & ○ & 을 & $\exists$ & $\cong$ & $\exists$ \\
\hline
\end{tabular}




\section{Neobjavljeni izvori}

Repubblica Italiana - Archivio di Stato di Venezia - fondo 0715 - Inquisitori sopra l'amministrazione dei pubblici ruoli (RI-ASVe-0715-Inquisitori ... pubblici ruoli)

\section{Literatura}

Čoralić, Lovorka. “Šibenski plemić Nikola Divnić (1654. - 1734.) - pukovnik hrvatske lake konjice (Cavalleria Croati)". Radovi Zavoda za povijesne znanosti HAZU u Zadru 54 (2012): 125-145.

Čoralić, Lovorka. "Riječani u mletačkim prekojadranskim postrojbama (18. stoljeće)”. Rijeka 18 (2013), br. 2: 11-25.

Čoralić, Lovorka. "Vojnici iz Hercegovine u mletačkim kopnenim postrojbama (18. stoljeće)”. Hum: Časopis Filozofskog fakulteta Sveučilišta u Mostaru 10 (2013): 162-182.

Čoralić, Lovorka. "Vojnici u mletačkim prekomorskim kopnenim postrojbama zavičajem iz Senja, Karlobaga te s područja Like i Krbave (18. stoljeće)". Senjski zbornik 40 (2013): 523-546.

Čoralić, Lovorka. “Zadarski patricij Lujo Detriko (1672. - 1749.) - zapovjednik hrvatske konjice (Cavalleria Croati)". Zbornik Odsjeka za povijesne znanosti Zavoda za povijesne i društvene znanosti HAZU 32 (2014): 99-129.

Čoralić, Lovorka. "Dubrovčani - vojnici u mletačkim pješačkim postrojbama (Fanti oltramarini) u 18. stoljeću”. Anali Zavoda za povijesne znanosti HAZU u Dubrovniku 53 (2015), br. 2: 293-309.

Čoralić, Lovorka. "Vojnici iz Bosne u mletačkim prekomorskim kopnenim postrojbama u 18. stoljeću”. Prilozi - Institut za istoriju u Sarajevu 44 (2015): 35-55.

Čoralić, Lovorka. “Zadarski otočani u mletačkim prekomorskim kopnenim postrojbama (18. stoljeće)”. Zbornik Odsjeka za povijesne znanosti Zavoda za povijesne i društvene znanosti HAZU 33 (2015): 173-198.

Čoralić, Lovorka. “Zadarski patricij Šimun Nassi - pukovnik hrvatskih konjanika u mletačkoj vojsci (početak 18. stoljeća)”. Povijesni zbornik - godišnjak za kulturu i povijesno naslijeđe 4 (2017), br. 5: 7-31.

Čoralić, Lovorka. "Albanski vojnici u mletačkim prekojadranskim kopnenim postrojbama (18. stoljeće)”. Povijesni prilozi 37 (2018), br. 54: 183-214.

Čoralić, Lovorka; Katušić, Maja. "Kotorski plemići Frano Buća, Gabrijel Vraćen i Nikola Paskvali - časnici mletačkih prekojadranskih vojnih postrojbi (prva polovica XVIII. st.)”. Povijesni prilozi 31 (2012), br. 42: 249-273.

Čoralić, Lovorka; Katušić, Maja. "Novigrađani - vojnici u mletačkim prekomorskim kopnenim postrojbama u 18. stoljeću”. U: Novigrad nekad i sad, uredio Slobodan Kaštela, 352-359. Zadar: Sveučilište u Zadru; HAZU; Matica hrvatska; Općina Novigrad, 2016.

Čoralić, Lovorka; Katušić, Maja. "Šibenčani u mletačkim prekojadranskim kopnenim postrojbama (18. stoljeće)". Radovi Zavoda za povijesne znanosti HAZU u Zadru 58 (2016): 147-190. 
Čoralić, Lovorka; Katušić, Maja. "Biograđani i Vranjani - vojnici u mletačkim prekomorskim kopnenim postrojbama (18. stoljeće)". U: Braća Vranjanin i vransko područje tijekom povijesti. Zbornik radova sa znanstvenoga skupa "Braća Vranjanin i vransko područje tijekom povijesti” održanog u Biogradu 25. travnja 2014., uredio Božo Došen, 455474. Zadar: Ogranak Matice hrvatske u Zadru, Općina Pakoštane, 2017.

Čoralić, Lovorka; Katušić, Maja. "Fanti oltramarini i Croati a cavallo - vojnici s otoka Ugljana u mletačkim prekomorskim kopnenim postrojbama u 18. stoljeću”. U: Kali, uredio Josip Faričić, 163-178. Zadar: Sveučilište u Zadru; HAZU; Općina Kali, 2017.

Čoralić, Lovorka; Katušić, Maja. "Kotoranin Tripun Gregorina (1719-1791) - pukovnik hrvatskih konjanika (Croati a cavallo)". Anali Zavoda za povijesne znanosti HAZU u Dubrovniku 55 (2017), br. 2: 375-406.

Favaloro, Francesco Paolo. L'Esercito Veneziano del '700. Ricerche e schizzi. Venezia: Filippi Editore, 1995.

Markulin, Nikola. "Mletačka vojna organizacija u Dalmaciji i Boki od Morejskog rata (1684. - 1699.) do Požarevačkog mira 1718.”. Doktorska disertacija, Sveučilište u Zadru, 2015.

Peričić, Šime. “Glavari i časnici Vojne krajine u Dalmaciji”. Radovi Zavoda za povijesne znanosti HAZU u Zadru 35 (1993): 219-252

Prelli, Alberto. Sotto le bandiere di San Marco: Le armate della Serenissima nel '600. Bassano del Grappa: Itinera progetti, 2012. 


\section{Lovorka Čoralić*}

\section{Spalatans as Croati a cavallo in the Venetian Trans-Adriatic Land Army during the $18^{\text {th }}$ Century}

\section{Summary}

As part of the study of the military history of Dalmatia and the Venetian Republic through several centuries of existence in a common state union, the share of Croats in the Venetian military forces has been assessed as extremely significant. Operating as the local (territorial) units, as well as members of professional forces (Fanti oltramarini - infantry; Croati a cavallo, Cavalleria Croati - cavalry), soldiers from Dalmatia made a notable contribution to the preservation of Venetian territorial acquisitions from Veneto (terraferma) to the south of the eastern Adriatic coast. Investigation of this issue is complex and requires an analysis of documents stored in the Archivio di Stato di Venezia and the State Archive in Zadar, as well as other Croatian and international archival institutions and libraries. Following several years of research on this issue, this paper focuses on the role of Spalatans in the Croatian cavalry under the standard of St Mark in the 18th century, and is based on an analysis of sources from the collection of Inquisitori sopra l'amministrazione dei pubblici ruoli in the central Venetian state archives. Based on the said documents, as well as previous historiographical insights, the author focuses on the time frame of the Spalatans' participation in the abovementioned cavalry unit, the method of their documentation, the duration of military service, the share of members from the same families, personal (physical) features of soldiers, the location of their documentation, and the command staff of the units in which they operated. The presence of Spalatans in Venetian cavalry can been observed throughout the century, while the places of their activity (documentation) reflect the distribution of Venetian acquisitions from the terraferma through Dalmatia and the Bay of Kotor to Greece, also testifying to the mobility of elite Venetian land units. The Spalatan cavalrymen fit into the wider sample of Croatian soldiers in the land forces of the Serenissima at that time in terms of age and personal (physical) features. The lists of soldiers reveal various aspects of the military careers of individual families such as the length of their military service, their career advancement, as well as a number of surnames that we believe can be an interesting source for studying the onomastics of Split during the period in question. The conclusion of the paper is that the Spalatans formed a very notable part of the Croatian cavalry under the standard of St Mark and that the analysis conducted here contributes to the military history of Dalmatia (in this case the city of Split) and the Venetian Republic in the last century of living in a common state.

Keywords: Split, Dalmatia, Venetian Republic, Cavalleria Croati, military history, 18th century

\footnotetext{
Lovorka Čoralić, Croatian Institute of History, Opatička 10, 10000 Zagreb, Croatia, E-mail:
} lovorka@isp.hr 